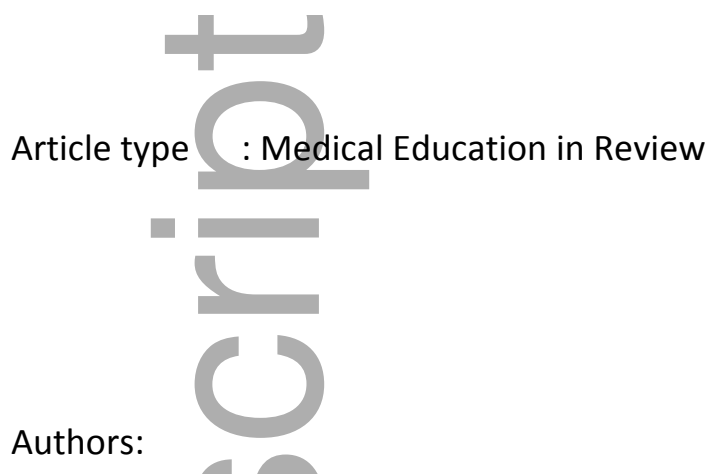

Gibson, Simone; Porter, Judi; Anderson, Amanda; Bryce, Andrea; Dart, Janeane; Kellow, Nicole;

Meiklejohn, Sarah; Volders, Evelyn; Young, Anne; Palermo, Claire

Affiliation all authors:

Monash University - Nutrition, Dietetics and Food

Notting Hill, Victoria

Australia

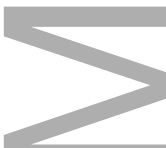

Corresponding author

Simone Jane Gibson

http://orcid.org/0000-0002-0008-9020

Monash University - Nutrition, Dietetics and Food

Dept Nutrition,Level 1, 264 Ferntree Gully Rd VIC Notting Hill Victoria 3168

Australia

T: 0447029510

\title{
Title: Clinical educators' skills and qualities in allied health: A systematic review
}

This is the author manuscript accepted for publication and has undergone full peer review but has not been through the copyediting, typesetting, pagination and proofreading process, which may lead to differences between this version and the Version of Record. Please cite this article as doi: $10.1111 /$ medu.13782

This article is protected by copyright. All rights reserved 


\section{Abstract}

Background: The skills and qualities of effective clinical educators are linked to improved student learning and ultimately patient care, however within allied health these have not yet been systematically summarised in the literature.

Aims: To identify and synthesise the skills and qualities of clinical educators in allied health and their effect on student learning and patient care.

Method: A systematic search of the literature was conducted across five electronic databases in November 2017. Study identification, data extraction and quality appraisal were performed in duplicate. Qualitative and quantitative data were extracted separately but analysed together using a thematic analysis approach whereby items used in quantitative surveys and themes from qualitative approaches were interpreted together.

Results: Data revealed seven educator skills and qualities: (i) Intrinsic and personal attributes of clinical educators (ii) Provision of skilful feedback (iii) Teaching skills (iv) Fostering collaborative learning (v) Understanding expectations (vi) Organisation and planning (vii) Clinical educators in their professional role. Across all themes was the concept of taking time to perform the clinical educator role. No studies used objective measurements as to how these skills and qualities affect learning or patient care

Discussion and conclusion: Despite much primary evidence of clinical educator skills and qualities, this review presents the first synthesis of this evidence in allied health. There is a need to examine clinical education from new perspectives to develop deeper understanding of how clinical educator qualities and skills influence student learning and patient care.

\section{Introduction}

Clinical education is a fundamental part of preparing and developing the health workforce. Working closely with students in authentic learning environments, clinical educators (CEs) provide guidance, feedback and assessment. As such they play a valuable role for student competency development in demanding workplace contexts. While the qualities of effective CEs in medicine have been synthesised (1-3), the skills and qualities of effective allied health clinical educators (CEs) have not been systematically explored. Expanding this knowledge to allied health is necessary to ensure we are preparing an effective interprofessional healthcare workforce. In medicine, the relationship between trainee and educator has been described as the most important factor for supervisory effectiveness (3). A comprehensive systematic review in medicine identified a range of skills and personal attributes of good CEs. Study results were commonly based on student and CE survey 
results or author opinions rather than objective outcomes of the CE attributes such as student learning or patient health outcomes (1). The role of effective CE in improving patient outcomes remains unknown.

While similarities may exist between medicine and allied health in terms of CE skills, qualities and behaviours, there is a need to identify if these hold true in allied health CE practice, and how these qualities might influence learning and patient care. Universities and teaching hospitals invest significant time and resources into CE support and training, with the belief that improving CE supervision skills will translate into improved student learning and subsequently good patient care. Understanding the depth and breadth of these skills and attributes, and if in fact student learning and patient care are enhanced, is imperative to justify these investments.

Allied health is a relatively new professional field compared with medicine and nursing having, emerged in the last century and consists of a range of disciplines (4). While there is no universally regarded classification, allied health consists of a diverse range of professions which are often grouped together in organisational structures. Allied health professions include audiology, dietetics, occupational therapy, pharmacy, radiography, physiotherapy, psychology, podiatry and social work amongst many others $(5,6)$. The professional groups vary in size, evidence base and length of time since being established, and they range from practical therapies such as physiotherapy, to counselling and social support by social workers. Allied health professions are typically much smaller than medicine and nursing and often rely on unification to advocate for their services. Although the allied health professions are diverse with their own specialised services, allied health clinicians share general and specialised skills involving interpersonal communication, patient assessment, management, education, discharge planning, working within multidisciplinary teams, advocacy, employing evidence-based practice and integrating the science of their fields in their clinical decision-making. They work across a range of settings from primary to tertiary care as well as preventative health with a strong emphasis on interprofessional collaboration. They often rotate through various clinics, wards and work settings, adapting to varying organisational structures (7). As a professional group, allied health sits uniquely apart from medicine and nursing in healthcare organisational structures and has distinctive challenges in being recognised in organisational hierarchy, and by medical and nursing staff (8). Clinical education in allied health uses a range of student supervision models and assessment processes, and contrasting with medicine and nursing, many programs have short placement times of less than 12 weeks, involve more intensive student supervision with lower student:CE ratios (9). Thus, the uniqueness of allied health clinical education warrants its own investigation, and the strong interprofessional nature of these professions may provide insights for medicine and nursing education. 
This study aims to identify and synthesise the skills and qualities of clinical educators in allied health and their effect on student learning and patient care.

\section{Methods}

A systematic review of the literature was conducted to answer the research question.

\section{Search strategy}

The systematic review was registered with PROSPERO (registration CRD42016037149). The Preferred Reporting Items for Systematic Reviews and Meta-analyses (PRISMA) framework was utilised to report the number of studies identified and screened, and the criteria used to determine eligibility for inclusion (10). A systematic search of the literature in MEDLINE (Ovid), the Cumulative Index to Nursing and Allied Health Literature (CINAHL Plus, EBSCO), PsycINFO (Ovid), Allied and Complementary Medicine Database (AMED, Ovid), and the Informit Education and Health Collections (Informit) was conducted on 28 November, 2017. Search results were limited to English language studies with no date restrictions applied. Full-text peer-reviewed papers and doctoral theses were eligible. The full MEDLINE search strategy is included in Appendix 1.

The search was structured in accordance with the PICO framework (population, intervention, comparator, outcome) and comprised an extensive range of search terms relating to "allied health" and "clinical education" and "learning". Allied Health terms included those relating to professions of audiology, dietetics and nutrition, occupational therapy, radiography, pharmacy, physiotherapy, podiatry, psychology, social work and speech pathology. Search results were exported into EndNote X8 software (X8.0.1, CWintertree Softward Inc.) for screening and duplicate removal. Screening was performed independently by two researchers using the Covidence platform (C Covidence 2018). Reference lists of selected studies were searched to identify additional relevant studies.

\section{Study selection and data extraction}

Titles and abstracts were screened in duplicate for inclusion by at least two authors, with disagreements being resolved between these two authors. Full publications were then screened in duplicate for inclusion. Conflicts were resolved by discussion between three authors (SG, JP, CP). Studies included involved allied health students, all fieldwork learning concerning patients, the outcome of clinical education, peer- or and inter- professional learning where clinical education was evaluated. Studies were excluded if they focussed on medicine or nursing, were simulated placement learning, or involved post-registration training. Fieldwork placement that did not involve patients and studies that did not involve primary data collection were also excluded. Data from 
included papers were extracted in duplicate by three authors (SG and JP or CP) including methods (study design, location, method of data collection), participants (sample size, characteristics), intervention (location, timeframe, length of placement) and outcomes (cultural competence, career choice, other). Studies were categorised by their primary methodology: qualitative or quantitative.

\section{Quality appraisal}

Each quantitative study was assessed independently and in duplicate using the Medical Education Research Study Quality Instrument (11) due to its purpose of appraising the quality of studies across a range of designs and established criterion validity. Parameters assessed included study design, sampling methods, type of data collected, validity of evaluation instrument, data analysis and outcomes. Qualitative studies were also appraised independently and in duplicate using the Critical Appraisal Skills Programme tool (12). Consensus was reached regarding its interpretation.

\section{Synthesis of results}

Data from qualitative studies were extracted and analysed as a whole using qualitative thematic analysis (13). Two researchers (SG \& CP) conducted independent coding of extracted data and theme development, coming together regularly throughout the process for clarification. The extracted data coded using an inductive approach. The codes were then grouped into categories which formed the coding structure and used to inform the development to themes. The findings of quantitative studies were analysed separately. As all quantitative papers required participants to rank or rate clinical educator skills based on what the researchers had already identified as key clinical educator skills, these skills and attributes listed in the surveys were extracted from the quantitative studies. All the skills and attributes were then coded with codes grouped into the coding structure developed from the qualitative studies. Constant comparison between the skills and qualities identified from each individual study and professional group was applied to explore similarities and differences between professional groups. The coding structure and codes from quantitative and qualitative studies were analysed together with themes extracted that answered the research questions. When authors came together to discuss the emerging themes they applied a critical approach to each other's interpretation, looking for alternative explanations for the identified data, and then reaching consensus.

Except for one specialist librarian, all researchers were qualified dietitians with experience across diverse public and private healthcare settings, working in large and small interprofessional teams, as well as direct experience in clinical education and educational research. 


\section{$\underline{\text { Results }}$}

The searches yielded 7375 studies after duplicates were removed (see Figure 1 for flow chart of included studies). A total of 43 studies were included with 26 studies included in the qualitative and 18 in the quantitative synthesis. One mixed methods study was included in both qualitative and quantitative synthesis (14). (Tables 1 and 2)

Studies were from USA (15-34), Australia (14, 35-43), Canada (28, 44-48), UK (49-52). South Africa (53) and Nigeria (54). Professions represented included physiotherapy $(15,19,21,27,29,31,33,36$, $38,45,49-54)$, occupational therapy $(20,26,28,37,39,41-43,47)$, dietetics $(22,34,40,44,46,48)$, pharmacy $(23,25,30)$, psychology (32), speech and language therapy (16), social work (24), radiography (18), genetic counsellors (17) and mixed allied health groups involving diagnostic radiography, nuclear medicine, dietetics, occupational therapy, physiotherapy, radiation therapy (14, 35).

Of the qualitative papers, fourteen investigated student perceptions, four investigated those of placement educators and seven investigated both. The qualitative methods for describing behaviours and skills of effective CEs used a range of methodologies involving students, academics, program directors and CEs (Table 2). These included qualitative analysis of focus groups, open-ended survey questions, interviews of CEs, analysis of clinical teacher award nominations and student critical incidents, while one study used a case study approach.

Eighteen papers used quantitative methods for investigating effective CE behaviours with all using surveys asking participants to rate CE behaviours, usually related to perceived importance (Table 1). Five studies derived the survey question content from the literature $(15,17,19,22,44)$, six were based on pre-existing instruments $(14,18,20,23,53,54)$, two were derived from the literature and student feedback $(50,51)$, one from student feedback (16), one from previous surveys (49) and three were derived from both the literature and pre-existing instruments $(35,36,53)$.

Descriptions of effective CE skills and attributes were identified by students' and educators' perceptions. Objective learning outcomes, student success and patient care were not measured in any of the studies.

\section{Quality appraisal}


Overall quality ratings of the quantitative studies using MERSQI ranged from 4.5-12 from a maximum score of 18 (Supplementary Table 1). Study designs generally involved single group cross sectional studies. Sampling was mostly from a single institution with varying response rates and all data collected by the studies was from participants' perspectives with no objective measurements of educational outcomes. The validity of the evaluation instruments and methodologies ranged from not being reported to full explanations. The data analysis domain scored highly for most studies. Outcomes were mostly measured as participants' perceptions and student satisfaction ratings. There were no patient outcomes measured in any of the studies.

Quality appraisal for the qualitative studies found that clear research questions were defined and studies used appropriate research methods. Some studies failed to consider researcher-participant relationships $(26,31,32,34,39,42,43,45,47,48,52)$, with six of these studies not reporting ethics approval. Rigour of data analysis was variable and all studies reported clear findings statements.

\section{Findings}

No objective learning outcomes, student success or patient care parameters were measured in any of the studies. Outcome measurements of the skills and qualities of clinical educators included CE and student descriptions of characteristics and attributes; how behaviours were perceived to influence learning and make students feel engaged; and perceptions of the distinguishing features of excellent CEs (Tables 1 and 2).

A range of skills behaviours and attitudes of CEs were identified as being valued by students and educators. These were refined to sets or themes: the personal attributes of CEs; provision of skilful feedback; teaching skills; fostering collaborative learning; understanding expectations; organisation and planning; the value of independent learning; and CEs in their professional role (Table 3). Some of the themes overlapped, for example a CE who has excellent interpersonal skills would likely to be reported to be more adept at nurturing a collaborative learning environment. Intrinsic personal qualities were acknowledged as difficult for individuals to acquire, but many skills identified were pragmatic behaviours such as being organised and having clear orientation and manuals. Across all the themes was the concept of time and the importance of CEs taking time to develop relationships and nurture learning. Also acknowledged within the included studies was the importance of time to prepare students for potentially stressful learning encounters, and time for reflection and discussion. 
Themes identified from the qualitative and quantitative studies were similar. Personal qualities such as friendliness, patience and kindness were highly valued by students and CEs. Students particularly valued CEs who displayed respect for them as an individual and as a future colleague. This fostered a sense of professional identity and instilled confidence in students' beliefs of their own ability. A collaborative learning model, where CEs were seen to also be on a learning continuum, was particularly valued by students.

Students and CEs in nearly all of the studies highlighted the value of CE feedback skills. Feedback was regarded as effective when it was constructive, regular, prompt and not degrading. Feedback as a reciprocal relationship impressed students in that CEs were open to improving themselves and valued the input of students towards patient care.

Teaching skills were regarded as beneficial for student learning although, as stated, no learning outcomes were measured. Scaffolding learning, providing appropriate challenges for student ability and fostering a culture of independence were rated as important skills for CEs to exhibit.

Clinical educators as role models and proficient in their job was regarded as a desirable quality. This related to not only their clinical knowledge and aptitude but other professional skills such as being a leader in their field, exhibiting patient-centred care, team work and communication skills. CEs advocating for and caring about their profession was also valued.

There were few differences between the different professions. All allied groups appeared to value the skills and qualities identified in the thematic analysis.

\section{Discussion}

This review aimed to identify and synthesise the skills and qualities of clinical educators in allied health and their effect on student learning and patient care. It found seven educator skills and qualities: (i) Intrinsic and personal attributes of clinical educators (ii) Provision of skilful feedback (iii) Teaching skills (iv) Fostering collaborative learning (v) Understanding expectations (vi) Organisation and planning (vii) Clinical educators in their professional role. The concept of taking time to perform the clinical educator role underpinned all skills and qualities. Of the published literature, no studies reported objective measurement of learning outcomes or patient care parameters. Due to the range of study methodologies and number of studies conducted within each allied health group, it was difficult to draw comparisons between different allied health disciplines. 
The CE role is integral to student learning and satisfaction (55). However students have mixed experiences on placement, largely related to their interactions with their CEs. Students entering clinical placements plunge from the structured and familiar academic environment into the busy, demanding and often stressful clinical setting. Clinical placement learning is complex with relationship building with peers and staff underpinning the creation of professional identity (56). These socio-cultural elements of practice learning shape development and are essential to the advancement of clinical and professional skills. Students have reported loss of confidence and bullying while on clinical placement (57), as well as ambiguous and inconsistent evaluation and assessment $(58,59)$. The skills and qualities of CE identified in this review may support the selection and training of $\mathrm{CE}$ into the future.

The personal attributes of CEs were perceived as paramount for providing a safe learning environment. This is consistent with review findings in medicine (1). Professional skills, including self-awareness, are essential for health professional practice, including clinical education. Health professionals involved in education may lack these skills themselves and there are barriers for teaching them in the clinical environment (60). There may be a need for those involved in clinical education to examine their personal qualities and identify areas for development or for selection processes to consider these intrinsic qualities in their CEs if they wish to foster a supportive and effective learning environment.

This review identified a range of skills and attributes of CEs that were highly valued by students and CEs involved in clinical education. These included personal attributes; provision of skilful feedback; teaching skills; fostering collaborative learning; understanding expectations; organisation and planning; the value of independent learning; and their professional role. An important distinction to the findings of this review compared to that in medical education was the importance of treating students as future colleagues and supporting the development of professional identity. Allied health groups are smaller and students may lack understanding of professional roles (61) until they are on placement, so CEs play a valuable role in establishing this identity. Also related to this was the value placed on CEs caring about and advocating for their profession. There was limited evidence as to how these skills translate beyond perceptions and ratings to tangible outcomes in terms of student skill development and patient care. Allied health students are often highly motivated and resourceful learners (62) who are likely to be capable of clinical placement success regardless of the attributes of their CE. Perceived learning is different to actual learning and trainees can demonstrate high-level skill performance after complex training, even when they believe they are not learning (63). Until 
further research provides concrete evidence to support a relationship between CE skills and student learning or success, definitive conclusions cannot be made.

The research question for this review could not be answered due to the notable lack of learning and patient outcomes measured in the studies identified. This requires looking beyond student, CE and faculty perceptions of individual skill importance and ratings. Current investment into CE professional development is extensive. But is this investment worthwhile when effective CE attributes have mostly been identified through student and educator opinions?

This review had a wide-ranging search strategy across multiple databases and professions, and included qualitative and quantitative studies. Limitations include English language restrictions and despite the extensive search strategy, not every allied health profession was represented. The heterogeneity of studies prevented meaningful comparisons between professions. The skills and qualities identified in the results were based on perceptions rather than objective outcomes.

This review found that since 1982, research in this area focussed on asking students and educators their opinions of what makes a good CE. Rather than continuing to invest in surveying students and educators regarding their beliefs, the development of robust measures of the true impact of CE skills and attributes on student learning is a priority area for future research.

\section{Implications for practice}

Investigating profession-specific skills will assist in targeting professional development required for CEs for individual allied health groups. Other possible outcome measures of CE skills could include student retention rates when on placement, student grades in units involving clinical placement, patient satisfaction or students' future success. Triangulating patient and student evaluations of clinicians/educators could provide further insights. Although linking CE skills and qualities to patient care outcomes is complex, further involvement of patients in evaluation processes is imperative to ensure that they remain central to the goals of clinical teaching and learning. We note that what makes a good educator may never be completely detached from subjective opinions due to the complex nature of student-CE relationships and there is a continued need to support CEs in developing these relationships to meet learner needs.

This systematic review revealed similar skills and qualities as to what makes a good CE to findings in medicine (1), but highlighted additional qualities including treating students as future colleagues and enhancing a sense of professional identity so this aspect should also be addressed when supporting CE development. 


\section{Conclusion}

This review found there has been much research in allied health over the past three decades investigating key stakeholders' (students and educators) perceptions of CEs skills and qualities, and this is the first time this has been systematically summarised. The key skills and qualities of effective clinical educators identified were based on perceptions, appear to be consistent across health professions and are related to intrinsic and personal attributes, provision of skilful feedback, teaching skills, ability to foster collaborative learning, understanding expectations, organisation and planning, and clinical educators in their professional role. Assisting allied health students develop a sense of professional identity was an important skill that may be unique to this group. There is a need to look at clinical education from perspectives beyond perceptions and satisfaction ratings to develop deeper understanding of how CE qualities and skills influence student learning and patient care.

\section{$\underline{\text { References }}$}

1. Sutkin G, Wagner E, Harris I, Schiffer R. What makes a good clinical teacher in medicine? A review of the literature. Acad Med. 2008;83(5):452-66.

2. Jochemsen-Van Der Leeuw H, Van Dijk N, Van Etten-Jamaludin F, Wieringa-De Waard M. The attributes of the clinical trainer as a role model: A systematic review. Acad Med. 2013;88(1):26-34.

3. Kilminster S, Jolly B. Effective supervision in clinical practice settings: a literature review. Med Educ. 2000;34(10):827-40.

4. Institute of Medicine (US), Committee to Study the Role of Allied Health Personnel. Allied Health Services: Avoiding Crises. (US). Washington (DC): National Academies Press (US); 1989.

5. Victorian Department of Health and Human Services. Allied Health: Therapy and services position paper. Australia, 2015

6. Association for the Schools of Allied Health Professions. What is Allied Health? United States, 2018. Accessed http://www.asahp.org/what-is/ 20 October 2018

7. Heiwe S, Kajermo KN, Tyni-Lenné R, Guidetti S, Samuelsson M, Andersson I-L, et al. Evidencebased practice: attitudes, knowledge and behaviour among allied health care professionals. Int J Qual Health Care. 2011;23(2):198-209.

8. Boyce R. Emerging from the shadow of medicine: allied health as a 'profession community'subculture. Health Sociol Rev. 2006;15(5):520-34. 
9. Darcy Associates. Best practice clinical learning environments within health services for undergraduate and early-graduate learners. Final Report. Australia, 2009.

Accessed https://www2.health.vic.gov.au/Api/downloadmedia/\%7B8B0BF699-2291-4EDA-824A721FD1656469\%7D 20 October 2018

10. Liberati A, Altman DG, Tetzlaff J, Mulrow C, Gøtzsche PC, loannidis JPA, et al. The PRISMA statement for reporting systematic reviews and meta-analyses of studies that evaluate health care interventions: explanation and elaboration. J Clin Epid. 2009 10//;62(10):e1-e34.

11. Reed D, Cook D, Beckman T, Levine R, Kern D, Wright S. Association between funding and quality of published medical education research. JAMA. 2007;298(9):1002-9.

12. Dixon-Woods $M$, Sutton A, Shaw R, Miller T, Smith J, Young B, et al. Appraising qualitative research for inclusion in systematic reviews: A quantitative and qualitative comparison of three methods. J Health Services Res Policy. 2007;12(1):42-7.

13. Bearman M. Quality and literature reviews: beyond reporting standards. Med Educ. 2016;50(4):382-4.

14. Perram A, Hills C, Johnston C, MacDonald-Wicks L, Surjan Y, James D, et al. Characteristics of an ideal practice educator: Perspectives from undergraduate students in diagnostic radiography, nuclear medicine, nutrition and dietetics, occupational therapy, physiotherapy and radiation therapy. Radiography. 2016;22(4):295-305. PubMed PMID: 118421753. Language: English.

15. Emery M. Effectiveness of the clinical instructor. Students' perspective. Phys Ther. 1984 Jul;64(7):1079-83

16. Fitzgerald M. Reflections on student perceptions of supervisory needs in clinical education. Perspect Admin Supervision. 2009;19(3):96-105

17. Higgins S, Veach P, MacFarlane I, Borders L, LeRoy B, Callanan N. Genetic counseling supervisor competencies: Results of a Delphi study. J Genetic Counseling. 2013 Feb;22(1):39-57.

18. Ingrassia J. Effective Radiography Clinical Instructor Characteristics. Radiologic Tech. 2011;82(5):409-20

19. Jarski R, Kulig K, Olson R. Allied health perceptions of effective clinical instruction. J Allied Health. 1989;18(5):469-78 19900201. Revision Date: 20150712. Publication Type: Journal Article. 20. Koski K, Simon R, Dooley N. Valuable occupational therapy fieldwork educator behaviors. Work. 2013;44(3):307-15.

21. Ozga K, Kenyon L, Engel A, Kool P, Sievers M, Stephenson P. Physical Therapist Students' Perceptions of Effective Clinical Instructor Behaviors: A Pilot Study. J Physi Ther Educ. 2016;30(4):3543

This article is protected by copyright. All rights reserved 
22. Wilson M. Dietetic preceptors perceive their role to include a variety of elements. J Am Diet Assoc. 2002 Jul;102(7):968-74.

23. Young S, Vos S, Cantrell M, Shaw R. Factors associated with students' perception of preceptor excellence. Am J Pharm Educ. 2014 Apr 17;78(3):53.

24. Adams MPJ. Social work field instructors' perceptions of core attributes: Implications for leadership and gatekeeping. Dissertation Abstracts International Section A: Humanities and Social Sciences. 2012;72(12-A):4755.

25. Astle J. Identification of desirable pharmacy preceptor characteristics and behaviors: A qualitative content analysis approach. Dissertation Abstracts International Section A: Humanities and Social Sciences. 2013;73

26. Christie B, Joyce P, Moeller P. Fieldwork experience, Part II: The supervisor's dilemma. Am J Occup Ther. 1985 Oct;39(10):675-81.

27. Greenfield B, Bridges P, Hoy S, Metzger R, Obuaya G, Resutek L. Exploring experienced clinical instructors' experiences in physical therapist clinical education: a phenomenological study. $J$ Phys Ther Educ. 2012 Fall2012;26(3):40-7.

28. Grenier M. Facilitators and Barriers to Learning in Occupational Therapy Fieldwork Education: Student Perspectives. Am J Occup Ther. 2015 Sep-Oct;69 Suppl 2:61-9.

29. Healey W. Physical therapist student approaches to learning during clinical education experiences: a qualitative study. Phys Ther Educ. 2008 Spring2008;22(1):49-58.

30. Ignoffo R, Chan L, Knapp K, Chan E, Ip E, Bandy J, et al. Efficient and effective precepting of pharmacy students in acute and ambulatory care rotations: A Delphi expert panel study. Am J Health-Syst Pharm. 2017 Oct 01;74(19):1570-8.

31. Kelly S. The Exemplary Clinical Instructor: A Qualitative Case Study. Phys Ther Educ. 2007 Spring;21(1):63-9.

32. McGinley M. The teach/treat debate in supervision: The student's perspective. Dissertation Abstracts International: Section B: The Sciences and Engineering. 2002 May;62(11-B):5383.

33. Rindflesch A, Hoversten K, Patterson B, Thomas L, Dunfee H. Students' description of factors contributing to a meaningful clinical experience in entry-level physical therapist professional education. Work. 2013;44(3):265-74.

34. Weitzenfeld D, Watson D, Argo J, Chapman S. Teaching behaviors of clinical instructors. Use of the critical incident technique to determine teacher effectiveness. J Am Diet Assoc. 1982 May;80(5):450-4.

35. Francis A, Hills C, MacDonald-Wicks L, Johnston C, James D, Surjan Y, et al. Characteristics of an ideal practice educator: Perspectives from practice educators in diagnostic radiography, nuclear 
medicine, nutrition and dietetics, occupational therapy and physiotherapy and radiation therapy. Radiography. 2016;22(4):287-94.

36. Milanese S, Gordon S, Pellatt A. Undergraduate physiotherapy student perceptions of teaching and learning activities associated with clinical education. Phys Ther Rev. 2013;18(6):439-44.

37. Copley J, Rodger S, Graham F, Hannay V. Facilitating student occupational therapists' mastery of occupation-centred approaches for working with children. Canadian J Occup Ther. 2011;78(1):37-44

38. Delany C, Bragge P. A study of physiotherapy students' and clinical educators' perceptions of learning and teaching. Med Teach. 2009;31(9):e402-11.

39. Hummell J. Effective fieldwork supervision: occupational therapy student perspectives. Aust Occup Ther J.1997;44(4):147-57.

40. Maher J, Pelly F, Swanepoel E, Sutakowsky L, Hughes R. The contribution of clinical placement to nutrition and dietetics competency development: A student-centred approach. Nutr Diet. 2015;72(2):156-62.

41. Mason L. A cooperative inquiry study to identify strategies for group supervision in occupational therapy fieldwork placements. Occ Ther Int. 1999;6(3):224-42.

42. Rodger S, Fitzgerald C, Davila W, Millar F, Allison H. What makes a quality occupational therapy practice placement? Students' and practice educators' perspectives. Aust Occ Ther J. 2011;58(3):195-202.

43. Rodger S, Thomas Y, Greber C, Broadbridge J, Edwards A, Newton J. Attributes of excellence in practice educators: The perspectives of Australian occupational therapy students Aust Occ Ther J. 2014 Jun;61(3):159-67.

44. Nasser R, Morley C, Cook S, Coleman J, Berenbaum S. Dietitians' Perceptions of Precepting: Knowledge, Skills, Attitudes, Barriers, and Training. Can J Diet Pract Res. 2014 Spring2014;75(1):7-14. 45. Cole B, Wessel J. How clinical instructors can enhance the learning experience of physical therapy students in an introductory clinical placement. Adv Health Sciences Educ. 2008;13(2):163-79. 46. MacLellan DL, Lordly D. The socialization of dietetic students: influence of the preceptor role. J Allied Health. 2008 ;37(2):e81-92.

47. Mulholland S, Derdall M, Roy B. The student's perspective on what makes an exceptional practice placement educator. Brit J Occ Ther. 2006;69(12):567-71.

48. Nasser R, Morley C, Cook SL, Coleman J, Berenbaum S. Dietitian preceptor knowledge, skills, attitudes, and training: key informant perceptions. Can J Diet Pract Res. 2011;72(3):130

49. Bennett R. Clinical education: perceived abilities/qualities of clinical educators and team supervision of students. Physiotherap). 2003 Jul;89(7):432-42.

This article is protected by copyright. All rights reserved 
50. Cross V. Perceptions of the ideal clinical educator in physiotherapy education. Physiotherapy. 1995;81(9):506-13.

51. Onuoha A. Effective clinical teaching behaviours from the perspective of students, supervisors and teachers. Physiotherapy. 1994;80(4):208-14.

52. Neville S, French S. Clinical education: students' and clinical tutors' views. Physiotherapy. 1991;77(5):351-4.

53. Ernstzen D, Bitzer E, Grimmer-Somers K. Physiotherapy students' and clinical teachers' perceptions of clinical learning opportunities: A case study. Med Teach. 2009;31(3):e102-e15.

54. Oyeyemi A, Oyeyemi A, Adegoke B, Rufai A. Physiotherapy clinical teachers' perceptions on important attributes in teaching - A Nigerian perspective. Eur J Physio. 2013;15(1):26-33.

55. Brown T, Williams B, Lynch M. Relationship between clinical fieldwork educator performance and health professional students' perceptions of their practice education learning environments. Nurs Health Sc. 2013;15(4):510-7.

56. Palermo C, Beck E, Chung A, Ash S, Capra S, Truby H, et al. Work-based assessment: Qualitative perspectives of novice nutrition and dietetics educators. J Hum Nutr Diet. 2014;27(5):513-21.

57. Hakojärvi H-R, Salminen L, Suhonen R. Health care students' personal experiences and coping with bullying in clinical training. Nurse Ed Tod. 2014;34(1):138-44.

58. Gibson S, Dart J, Bone C, Palermo C. Dietetic Student Preparedness and Performance on Clinical Placements: Perspectives of Clinical Educators. J Allied Health. 2015;44(2):101-7.

59. Palermo C, Chung A, Beck EJ, Ash S, Capra S, Truby H, et al. Evaluation of assessment in the context of work-based learning: Qualitative perspectives of new graduates. Nutr Diet. 2015;72(2):143-9.

60. Gibson S, Molloy E. Professional skill development needs of newly graduated health professionals: A systematic literature review. Foc Health Prof Educ. 2012;13(3):71-83.

61. Porter J, Wilton A. Professional identity of allied health staff. J Allied Health. 2018. In press

62. Becker M, Dudley-Javoroski S, Shields RK. Professionalism values in health science education: Self- and peer-Assessment of faculty, staff, and students. J Allied Health. 2017;46(3):178-84.

63. Brown PC, Roediger HL, McDaniel MA. Make it stick: Harvard University Press; 2014.

This article is protected by copyright. All rights reserved 
Table 1. Summary of quantitative studies describing clinical educator qualities and behaviours included in review

\begin{tabular}{|c|c|c|c|c|c|}
\hline \multirow{2}{*}{\multicolumn{2}{|c|}{$\begin{array}{l}\text { Author, date Setting, Sample } \\
\text { Location } \\
\text { Dietetics }\end{array}$}} & \multirow[t]{2}{*}{ Methodology } & \multirow{2}{*}{$\begin{array}{l}\text { How skills/behaviours were } \\
\text { identified }\end{array}$} & \multicolumn{2}{|c|}{ Summary of clinical educator qualities/behaviours evaluated } \\
\hline & & & & & \\
\hline $\begin{array}{l}\text { Nasser } \\
2014 \\
\text { Canada }\end{array}$ & 750 preceptors & $\begin{array}{l}\text { Online } 98 \text { item survey derived } \\
\text { from literature. } \\
45 \% \text { respondents had } 6 \text { or } \\
\text { more years preceptor } \\
\text { experience }\end{array}$ & $\begin{array}{l}\text { Preceptor rated importance of } \\
\text { skills }\end{array}$ & $\begin{array}{l}\text { Evaluation and assessment skills } \\
\text { Promote learning and skill } \\
\text { development } \\
\text { Extensive clinical knowledge in own } \\
\text { area } \\
\text { Know trainees learning styles } \\
\text { Challenge learners } \\
\text { Provide constructive feedback } \\
\text { Identify learner's performance } \\
\text { problems } \\
\text { Identify learning opportunities } \\
\text { Establish environment that } \\
\text { encourages learners to ask } \\
\text { questions } \\
\text { Help learners feel comfortable } \\
\text { Desire to impart knowledge } \\
\text { Allow learners to make mistakes } \\
\text { Recognise external and internal } \\
\text { factors influencing learner } \\
\text { performance }\end{array}$ & $\begin{array}{l}\text { Not overwhelming learners } \\
\text { Empower learners to take control } \\
\text { of their own learning } \\
\text { Understand learners might be } \\
\text { nervous } \\
\text { Commit to learner development } \\
\text { Consider learners as colleagues } \\
\text { Enjoy their role as preceptor } \\
\text { Confident in teaching } \\
\text { Assess learner needs and adapt } \\
\text { Perceive self as teacher } \\
\text { Derive intrinsic satisfaction from } \\
\text { teaching } \\
\text { Recognise mutual learning occurs } \\
\text { when teaching }\end{array}$ \\
\hline $\begin{array}{l}\text { Wilson }^{19} \\
2002 \\
\text { US }\end{array}$ & 265 Preceptors & $\begin{array}{l}\text { Cross-sectional } \\
\text { Survey - } 70 \text { item developed } \\
\text { from literature ranking most } \\
\text { important behaviours of } \\
\text { preceptors }\end{array}$ & $\begin{array}{l}\text { Preceptors beliefs of most } \\
\text { important behaviours }\end{array}$ & $\begin{array}{l}\text { Arrange useful learning experiences } \\
\text { to accomplish tasks } \\
\text { Assess interns prior content } \\
\text { knowledge } \\
\text { Identify the usefulness of self- }\end{array}$ & \\
\hline
\end{tabular}

This article is protected by copyright. All rights reserved 


\begin{tabular}{|c|c|c|c|c|}
\hline & 0 & & & $\begin{array}{l}\text { evaluation with the intern } \\
\text { Help intern become aware of } \\
\text { strengths and weaknesses } \\
\text { Encourage intern to determine } \\
\text { learning experiences to achieve } \\
\text { objectives } \\
\text { View intern as prospective co-worker }\end{array}$ \\
\hline $\begin{array}{l}\text { Genetic } \\
\text { Counsello }\end{array}$ & 10 & & & \\
\hline $\begin{array}{l}\text { Higgins }^{14} \\
2013 \\
\text { US }\end{array}$ & $\begin{array}{l}\text { Program directors } \\
\text { and supervisors }\end{array}$ & $\begin{array}{l}\text { Cross-sectional survey - } \\
\text { online Delphi survey to } \\
\text { determine most important } \\
\text { standards for counselling } \\
\text { supervisors ( } 24 \text { items in round } \\
1 \text { of the Delphi). Questions } \\
\text { based on literature } \\
\mathrm{n}=75 \text { (round 1) with } 3 \text { Program } \\
\text { directors and } 62 \text { Supervisors } \\
61 \text { (round 2) survey based on } \\
\text { Standards for Counselling } \\
\text { Supervisors (Dye and Borders } \\
1990 \text { ) where participants rated } \\
\text { behaviours. } \\
\text { Then interpretive content } \\
\text { analysis and developed } \\
\text { concepts }\end{array}$ & $\begin{array}{l}\text { Program directors and supervisors } \\
\text { ratings of the importance of skills } \\
\text { required for clinical placement } \\
\text { supervisors }\end{array}$ & $\begin{array}{l}\text { Student Evaluation -Goal Setting, } \\
\text { evaluation, feedback, remediation } \\
\text { Student Centered Supervision } \\
\text { Personal Traits and Characteristics } \\
\text { Relationship Building and } \\
\text { Maintenance } \\
\text { Guidance and Monitoring of Patient } \\
\text { Care }\end{array}$ \\
\hline \multicolumn{5}{|c|}{$\begin{array}{l}\text { Occupation } \\
\text { al Therapy }\end{array}$} \\
\hline Koski" & 37 OT students: & Cross sectional study. Survey & Ranked order of importance of & Administration - organised, \\
\hline
\end{tabular}

This article is protected by copyright. All rights reserved 


\begin{tabular}{|c|c|c|c|c|c|}
\hline 2011 & 85 fieldwork & ranking behaviours of effective & skills & schedules, manuals, policies & \\
\hline US & $\begin{array}{l}\text { educators with } \\
65.9 \% \text { having over } \\
5 \text { years supervision } \\
\text { experience }\end{array}$ & $\begin{array}{l}\text { educators } \\
\text { Questionnaire developed } \\
\text { based on Self Assessment } \\
\text { Tool for Fieldwork Educator } \\
\text { Competency (SAFECOM). } \\
\text { Importance of each item } \\
\text { ranked total } 27 \text { items }\end{array}$ & & $\begin{array}{l}\text { Evaluation - expectations, } \\
\text { assessment, facilitates student } \\
\text { reflection } \\
\text { Supervision and education - } \\
\text { scaffolds learning, collaborative, } \\
\text { feedback, sensitive to learning styles } \\
\text { Professional practice - skilled in } \\
\text { field, client-centred, teamwork }\end{array}$ & \\
\hline \multicolumn{6}{|l|}{ Pharmacy } \\
\hline $\begin{array}{l}\text { Young } \\
2014 \\
\text { US }\end{array}$ & $\begin{array}{l}2,639 \text { student } \\
\text { evaluations }\end{array}$ & $\begin{array}{l}\text { Retrospective audit of } \\
\text { completed student placement } \\
\text { evaluations over } 2009-2012 \\
14 \text { items relating to rating of } \\
\text { preceptor performance }\end{array}$ & $\begin{array}{l}\text { Student rating of preceptor } \\
\text { performance }\end{array}$ & $\begin{array}{l}\text { This preceptor is interested in } \\
\text { teaching this rotation. } \\
\text { This preceptor related to me as an } \\
\text { individual. } \\
\text { This preceptor encouraged students } \\
\text { to actively participate in discussions } \\
\text { and problem-solving exercises. } \\
\text { Students were encouraged to use } \\
\text { resource materials. } \\
\text { The preceptor described their } \\
\text { approach to thinking about } \\
\text { therapeutic problems } \\
\text { This preceptor was readily available } \\
\text { to answer questions and concerns } \\
\text { Good direction and feedback were } \\
\text { provided. } \\
\text { The preceptor is knowledgeable in } \\
\text { their response to questions or their } \\
\text { approach to therapy }\end{array}$ & $\begin{array}{l}\text { This preceptor evaluated me at the } \\
\text { mid-point and the end of the } \\
\text { rotation } \\
\text { This preceptor evaluated me at the } \\
\text { end of the rotation in a manner } \\
\text { which was helpful to me } \\
\text { This preceptor served as a role } \\
\text { model for a pharmacist practicing } \\
\text { in this practice setting } \\
\text { The goals and objectives of the } \\
\text { rotation were outlined and/or } \\
\text { explained at the beginning of the } \\
\text { rotation } \\
\text { Rotation activities were well- } \\
\text { organized and structured. } \\
\text { The preceptor discussed patient } \\
\text { care and/or practice-related issues } \\
\text { with me }\end{array}$ \\
\hline
\end{tabular}

This article is protected by copyright. All rights reserved 


\section{Physiothera}

py

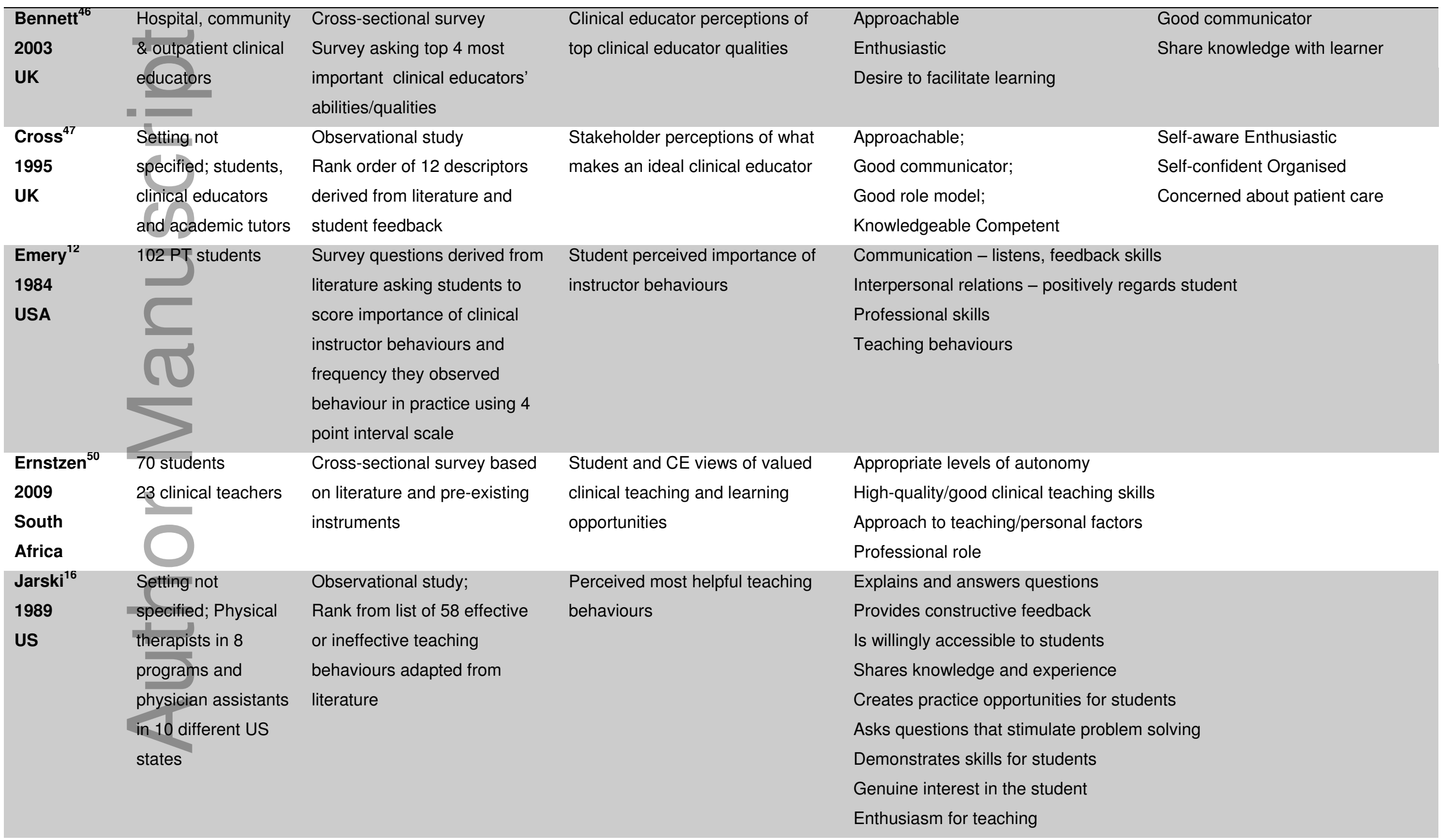

This article is protected by copyright. All rights reserved 


\begin{tabular}{|c|c|c|c|c|}
\hline & & & & $\begin{array}{l}\text { Friendly and outgoing } \\
\text { Sensitive to patient needs } \\
\text { Well prepared } \\
\text { Actively promotes discussions } \\
\text { Emphasises problem solving approaches rather than solutions }\end{array}$ \\
\hline $\begin{array}{l}\text { Milanese }^{33} \\
2013 \\
\text { Australia }\end{array}$ & $\begin{array}{l}48 \text { final year PT } \\
\text { students }\end{array}$ & $\begin{array}{l}\text { Cross sectional, non- } \\
\text { experimental survey based on } \\
\text { (Ernstzen 2009) questionnaire } \\
\text { asked students to rate how } \\
\text { much they learnt during } \\
\text { placement from a list of } \\
\text { teaching/learning opportunities }\end{array}$ & Student reported learning ratings & $\begin{array}{l}\text { Patient-centred activities for learning } \\
\text { Opportunities for student to present knowledge and learning } \\
\text { Feedback } \\
\text { Student assessment by range of stakeholders } \\
\text { Give student responsibilities and collaborates }\end{array}$ \\
\hline $\begin{array}{l}\text { Oyeyemi }^{51} \\
2013 \\
\text { Nigeria }\end{array}$ & $\begin{array}{l}\text { Clinicians and } \\
\text { academic faculty in } \\
\text { five universities and } \\
\text { affiliating teaching } \\
\text { hospitals }\end{array}$ & $\begin{array}{l}\text { Survey using McGill CTE } \\
\text { validated tool measuring } \\
\text { effective clinical teaching - } \\
\text { rated importance of attributes } \\
\text { of effective clinical teaching }\end{array}$ & $\begin{array}{l}\text { Clinical instructor ratings of skill } \\
\text { importance }\end{array}$ & $\begin{array}{l}\text { Inspire confidence } \\
\text { Open communication } \\
\text { Encouraging questions } \\
\text { Enthusiastic, interested in students } \\
\text { Friendly to students and colleagues } \\
\text { Encourage problem solving } \\
\text { Dependable } \\
\text { Present divergent viewpoints for discussion } \\
\text { Encourage student-led learning } \\
\text { Emphasis concepts rather than factual recall }\end{array}$ \\
\hline $\begin{array}{l}\text { Onuoha }^{48} \\
1994 \\
\text { UK }\end{array}$ & $\begin{array}{l}85 \text { students } \\
75 \text { clinical } \\
\text { supervisors } \\
55 \text { teachers }\end{array}$ & $\begin{array}{l}\text { Survey derived from student } \\
\text { feedback and the literature } \\
\text { asked participants to rate } \\
\text { importance of clinical educator } \\
\text { behaviours }\end{array}$ & $\begin{array}{l}\text { Stakeholders ratings of } \\
\text { importance of behaviours }\end{array}$ & $\begin{array}{l}\text { Clinically competent } \\
\text { Good time management } \\
\text { Leader } \\
\text { Good explanations } \\
\text { Enthusiastic about clinical education } \\
\text { Role model } \\
\text { Clear expectations } \\
\text { Provides experiences suited to ability } \\
\text { Allows a measure of independence } \\
\text { Available }\end{array}$ \\
\hline
\end{tabular}

This article is protected by copyright. All rights reserved 
Accurate documentation of evaluation

Constructive criticism

Treats student collegially

Attentive to student views

\begin{tabular}{|c|c|c|c|c|}
\hline & J & & & $\begin{array}{l}\text { Feedback } \\
\text { Non-threatening }\end{array}$ \\
\hline $\begin{array}{l}\text { Ozga }^{18} \\
2016 \\
\text { US }\end{array}$ & 103 students & $\begin{array}{l}\text { Cross-sectional survey based } \\
\text { on pre-existing survey asking } \\
\text { participants to rate how } \\
\text { important } 43 \text { observable } \\
\text { clinical instructor skills were }\end{array}$ & $\begin{array}{l}\text { Students rating of importance of } \\
\text { behaviours }\end{array}$ & $\begin{array}{l}\text { Communication - feedback (honest, private, timely, useful), clear, open, } \\
\text { active listener } \\
\text { Interpersonal relations - cares about patients, treats student as person, } \\
\text { professional, supportive, empathetic } \\
\text { Professional skills - competent, team player, role model, good at explaining } \\
\text { interventions and problem solving, leadership } \\
\text { Teaching - available, provides teachable moments, scaffolds learning, is } \\
\text { accurate and objective in documenting student performance evaluation, } \\
\text { relates academic knowledge to clinical practice, manages the student's } \\
\text { time constructively, is consistent with the academic program, observes } \\
\text { performance in a discretely, schedules regular meetings, plans ahead and } \\
\text { organised }\end{array}$ \\
\hline $\begin{array}{l}\text { Radiotherap } \\
\text { y }\end{array}$ & & & & \\
\hline $\begin{array}{l}\text { Ingrassia }{ }^{15} \\
2011 \\
\text { US }\end{array}$ & $\begin{array}{l}\text { Setting not } \\
\text { described }\end{array}$ & $\begin{array}{l}\text { Observational study, } \\
\text { questionnaire based on pre- } \\
\text { existing instruments from other } \\
\text { disciplines administered via } \\
\text { electronic survey tool }\end{array}$ & $\begin{array}{l}\text { Ranked importance of behavioural } \\
\text { characteristics of CEs }\end{array}$ & $\begin{array}{l}\text { Professional competence } \\
\text { Teaching ability } \\
\text { Evaluation skills } \\
\text { Interpersonal relationship skills }\end{array}$ \\
\hline $\begin{array}{l}\text { Speech } \\
\text { language } \\
\text { therapy }\end{array}$ & & & & \\
\hline $\begin{array}{l}\text { Fitzgerald }^{13} \\
2009 \\
\text { US }\end{array}$ & $\begin{array}{l}\text { Distance and } \\
\text { traditional } \\
\text { educational delivery } \\
\text { model speech }\end{array}$ & $\begin{array}{l}\text { Observational study; Self- } \\
\text { assessment surveys and } \\
\text { rating scales }\end{array}$ & $\begin{array}{l}\text { Top supervisory aspects indicative } \\
\text { of student and educator needs }\end{array}$ & $\begin{array}{l}\text { Top supervisory aspects across all groups: } \\
\text { Talking in times of difficulty, constructive criticism, assistance with specific } \\
\text { treatment ideas, resources for evidence-based practice, encouraging } \\
\text { critical thinking, allowing creativity, collegial interactions, exercising }\end{array}$ \\
\hline
\end{tabular}

This article is protected by copyright. All rights reserved 


\section{sional}

\section{Francis $^{32}$}

2016

Australia

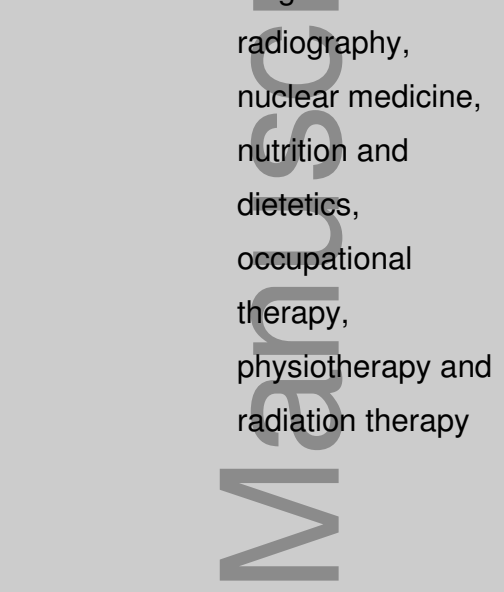

\section{Perram $^{11}$}

\section{6}

Australia

\section{5 students from}

diagnostic

radiography,

nuclear medicine

nutrition and

dietetics,

occupational

therapy,

physiotherapy,

radiation therapy

\section{Prospective, cross-sectional}

descriptive survey design;

survey based on literature and

pre-existing instrument asking

participants to rank

characteristics in order of

importance

\section{CE perceptions ranking of most important practice educato \\ characteristics}

cissor

\section{Cross-sectional anonymous}

survey derived from existing

survey.

Students asked to rate

importance of practice

educator characteristics

\section{Students ratings and rankings of} most import qualities of practice educators

\section{Feedback skills}

Being non-judgemental

Professionalism

Clear

Listening skills

Enthusiasm

Sincerity

Clinically competent

Organised

Role model

Available

Well prepared

Respects student autonomy

Scholarly activity

Non-judgemental, clarity, feedback skills, awareness, professionalism, sincerity, enthusiasm, clinical competence, availability, listening skills, well prepared, organisational skills, respects student autonomy, practices evidence based practice, role model, scholarly activity 
Table 2. Summary of qualitative studies describing clinical educator qualities and behaviours included in review

\begin{tabular}{|c|c|c|c|c|}
\hline $\begin{array}{l}\text { Author, date } \\
\text { Location }\end{array}$ & $\begin{array}{l}\text { Profession } \\
\text { Setting } \\
\text { Sample }\end{array}$ & Methodology & $\begin{array}{l}\text { How skills/behaviours } \\
\text { were identified }\end{array}$ & Summary of clinical educator qualities/behaviours evaluated \\
\hline Dietetics & & & & \\
\hline $\begin{array}{l}\text { MacLellan }{ }^{43} \\
2008 \text { Canada }\end{array}$ & $\begin{array}{l}\text { Setting not } \\
\text { specified } \\
284 \text { dietetic } \\
\text { interns }\end{array}$ & $\begin{array}{l}\text { Qualitative study using } \\
\text { methodological } \\
\text { hermeneutics analysing } \\
\text { interns and students' } \\
\text { answers to open-ended } \\
\text { survey questions }\end{array}$ & $\begin{array}{l}\text { Student perceptions of } \\
\text { CE role and effect on } \\
\text { student stress }\end{array}$ & $\begin{array}{l}\text { Treat interns as equals } \\
\text { Recognise power imbalance between students and staff } \\
\text { Spend time with trainees } \\
\text { Flexible } \\
\text { Encourage open learning experiences }\end{array}$ \\
\hline $\begin{array}{l}\text { Maher }^{37} \\
2015 \\
\text { Australia }\end{array}$ & $\begin{array}{l}\text { Hospitals } \\
26 \text { graduates } \\
\text { recently } \\
\text { completed } \\
\text { clinical } \\
\text { placement }\end{array}$ & $\begin{array}{l}\text { Thematic analysis } \\
\text { using descriptive and } \\
\text { interpretive analysis of } \\
\text { semi-structured } \\
\text { interviews }\end{array}$ & $\begin{array}{l}\text { Recent graduate } \\
\text { perceptions of CEs and } \\
\text { behaviours that } \\
\text { contributed to } \\
\text { competency development }\end{array}$ & $\begin{array}{l}\text { Creating welcoming and friendly environment, eg. having lunch with students enhanced students } \\
\text { sense of belonging to the team } \\
\text { Creating sense of belonging to profession } \\
\text { Providing opportunities to contribute clinical opinions which were valued and respected } \\
\text { Provide opportunities for autonomy } \\
\text { Independence and responsibility provided which was relevant to growing ability } \\
\text { Constructive criticism } \\
\text { Trust } \\
\text { Friendly and approachable } \\
\text { Interest in teaching and student learning } \\
\text { Younger and more relaxed } \\
\text { Also outlined negative practices }\end{array}$ \\
\hline $\begin{array}{l}\text { Nasser }^{45} \\
2011 \\
\text { Canada }\end{array}$ & $\begin{array}{l}\text { Clinical, } \\
\text { community, } \\
\text { food service, } \\
\text { research, } \\
\text { business } \\
\text { and industry } \\
49 \\
\text { experienced }\end{array}$ & $\begin{array}{l}\text { Qualitative analysis of } \\
\text { open-ended survey } \\
\text { questions }\end{array}$ & $\begin{array}{l}\text { Experienced preceptors } \\
\text { descriptions of the } \\
\text { knowledge, skills, and } \\
\text { attitudes that dietitian } \\
\text { preceptors must possess. }\end{array}$ & $\begin{array}{l}\text { SKILLS assessing, coaching, communicating (particularly through active listening), resolving } \\
\text { conflict, evaluating, planning, researching, teaching/facilitating, and managing time. } \\
\text { ATTITUDES } \\
\text { Attitudes toward learners: Accepts different backgrounds, styles, approaches; Commits to the } \\
\text { success of the learner; Is empathic about learners' learning needs; Enjoys student contact; } \\
\text { personal interest in students; Has realistic expectations of the learner; Supports the learner in } \\
\text { developing her or his own approach to dietetic practice; Views interns/students as colleagues; } \\
\text { Attitudes toward the profession: Views precepting as part of professional responsibility; Is }\end{array}$ \\
\hline
\end{tabular}

This article is protected by copyright. All rights reserved 
preceptors

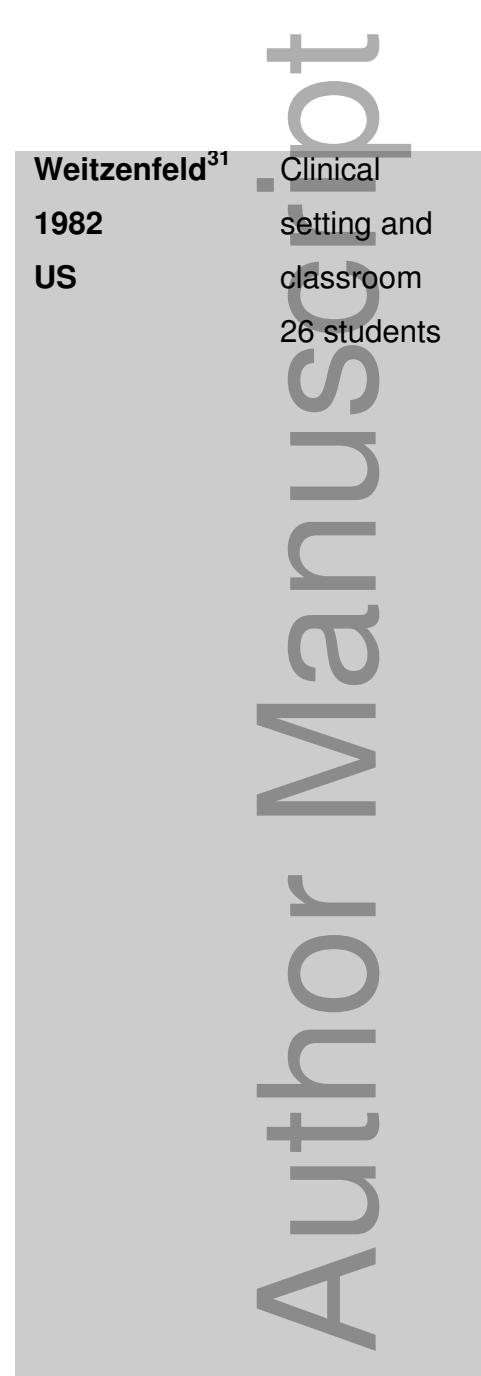

passionate and positive about dietetics and the profession; Attitudes toward teaching; Allows students to make mistakes and learn from them; Is open to new ideas/ways of doing things; Has a love of teaching and learning and wants to teach learners; Attitudes toward training: Commits to the teaching and learning of learners; Views training as mutual learning for the learner and the preceptor; Views the training of learners as valuable

Demonstrate empathy. open and honest, nonjudgmental, positive, role modelling

\section{Descriptive survey} approach of 156 critical incident interviews about clinical instructors by 26 students
Students perceptions of effective and ineffective supervision

\section{TEACHING TCHNIQUES AND METHODS-}

Knows subject matter

Gives accurate answers to questions

Uses methods of teaching other than lecture

Arranges chairs in a circle to facilitate discussions

Uses visual aids

Demonstrates how she would have given a diet instruction or handled a situation

Demonstrates the use of all equipment, audio-visuals etc.

Allows time for student to practice what has been demonstrated

Orients students to each new rotation

Situations are made realistic

Mediates discussion

INTERACTION-

Points out good aspects of a diet instruction given by the student

Ask for student opinions and feelings

Listens to problems and clarified the situation

Comforts student by expressing an understanding for doing something the first time

Makes student feel relaxed and at ease

Does not make student feel stupid or out of place

Allows student to explain how she would handle a situation

Spends time discussing an issue

Introduces student to her patients

Spends time answering questions

EVALUATION:

Explains evaluation measures

This article is protected by copyright. All rights reserved 
Gives constructive criticism

Gives examples of how to strengthen weaknesses

Gives direct feedback on practice videotapes

\section{Occupational}

therapy

\begin{tabular}{|c|c|c|c|c|}
\hline $\begin{array}{l}\text { Christie }^{23} \\
1985 \\
\text { USA }\end{array}$ & $\begin{array}{l}\text { Hospitals } \\
188 \\
\text { therapists } \\
\text { and } 127 \\
\text { students }\end{array}$ & $\begin{array}{l}\text { Results of open ended } \\
\text { questionnaires } \\
\text { were analysed. }\end{array}$ & $\begin{array}{l}\text { Student and therapists } \\
\text { views of distinguishing } \\
\text { factors of effective } \\
\text { supervisors }\end{array}$ & $\begin{array}{l}\text { Interpersonal and communication skills, active listening, openness and honesty, attitudes, } \\
\text { feedback (timely, constructive, consistent, and growth-promoting), adaptable supervisory } \\
\text { approach, structured, individualised, flexible, open-minded, available, competent as a clinician and } \\
\text { as an educator, role model, organized, supportive, empathetic, non-defensive, concern for the } \\
\text { students' growth, commitment to the supervisory role, sensitivity to students' needs, patience, } \\
\text { objectivity and enthusiasm }\end{array}$ \\
\hline $\begin{array}{l}\text { Copley }^{34} \\
2011 \\
\text { Australia }\end{array}$ & $\begin{array}{l}\text { Children's } \\
\text { occupational } \\
\text { therapy clnic } \\
9 \text { students } \\
\text { and } 2 \\
\text { practice } \\
\text { educators }\end{array}$ & $\begin{array}{l}\text { Qualitative } \\
\text { phenomenological } \\
\text { approach involving } \\
\text { interviews }\end{array}$ & $\begin{array}{l}\text { Student and CE } \\
\text { perceptions of CE } \\
\text { approaches to help } \\
\text { student learning }\end{array}$ & $\begin{array}{l}\text { Modelling of practice } \\
\text { Debriefing and performance-specific feedback } \\
\text { Structuring learning, observation, and reporting } \\
\text { Opportunity for practice }\end{array}$ \\
\hline $\begin{array}{l}\text { Grenier }^{25} \\
2015 \\
\text { Canada \& US }\end{array}$ & $\begin{array}{l}\text { Fieldwork } \\
\text { placements } \\
29 \text { students }\end{array}$ & $\begin{array}{l}\text { Online open survey } \\
\text { analysed using } \\
\text { inductive grounded } \\
\text { theory approach to } \\
\text { content analysis }\end{array}$ & $\begin{array}{l}\text { Student perceptions of } \\
\text { the characteristics of their } \\
\text { CEs and their teaching } \\
\text { behaviours and their } \\
\text { effects on learning }\end{array}$ & $\begin{array}{l}\text { Well-developed interpersonal skills, demonstrated qualities of professionalism, realistic } \\
\text { expectations of students, created positive learning spaces for students, took consideration into } \\
\text { individual knowledge and skills, gave responsibility, were approachable, created safe environment, } \\
\text { passion for profession/highly motivated, encouraged active student participation in treatment } \\
\text { sessions, rounds and team meetings, provided regular constructive feedback to allow students to } \\
\text { understand strengths and weaknesses, provided relevant tasks, gave independence, established } \\
\text { clear objectives and expectations, encouraged frequent discussions, took advantage of teachable } \\
\text { moments, adapt to students different learning styles and tailor fieldwork experience, mentor vs } \\
\text { supervisor. }\end{array}$ \\
\hline Hummell $^{36}$ & Fieldwork & Qualitative analysis of & Student perceptions of & Approachable \\
\hline
\end{tabular}

This article is protected by copyright. All rights reserved 


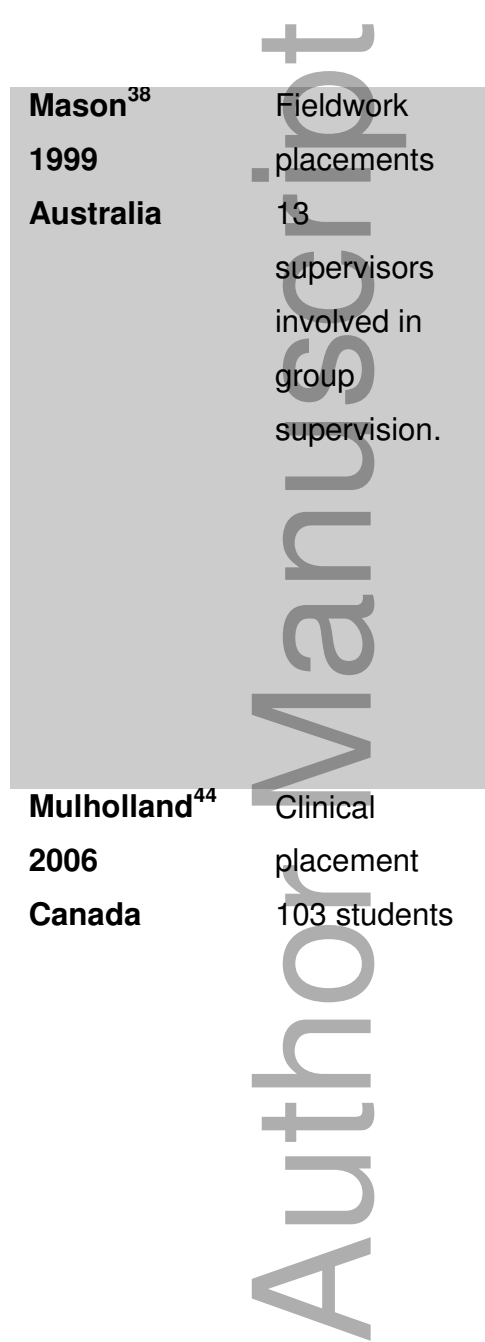

\section{Cooperative enquiry} approach. Reflectionaction cycle generated data

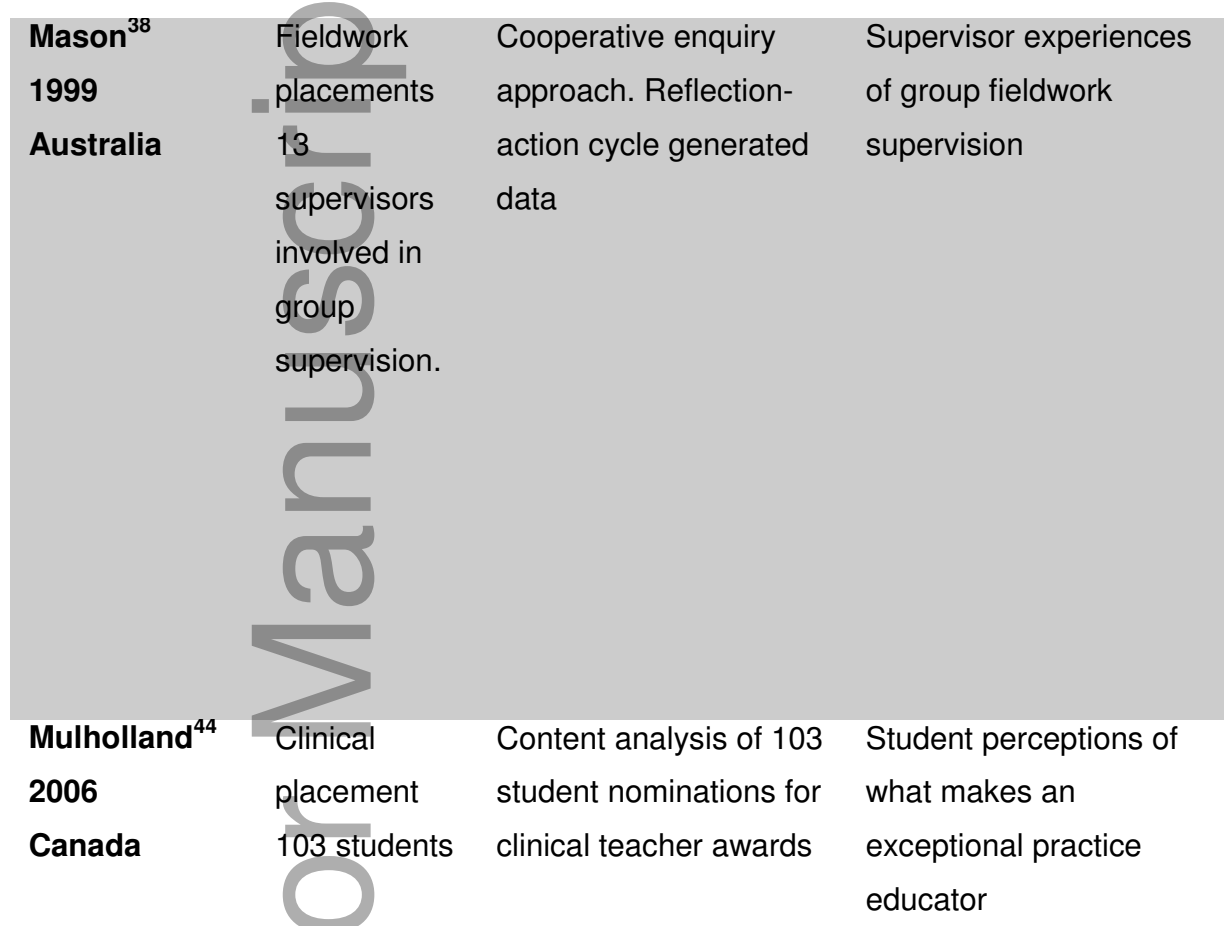

This article is protected by copyright. All rights reserved

\section{Easy to talk to}

Listened to student's opinions and ideas

Interested in students

Exhibiting respect for students

Providing support when needed

Awareness and managing differing abilities and learning styles of students in the group

Clear expectations of level of participation

Individual feedback where required

Be explicit about learning taking place - guide students to be consciously aware of learning opportunities in the fieldwork setting

Relate observations to theory

Promote informal opportunities for interacting with patients

Prepare learning objectives pertinent to fieldwork setting

Establish learning objectives early

Articulating a frame of reference to guide students in recognizing what they were learning -starting with a broader perspective, relating this to functional abilities of the client and then breaking these down to smaller components. Supervisors defined a domain of concern, for example, quality-of-life issues, and then related this to the clients and the activities provided for them.

\section{Creating a positive learning environment}

Facilitating the whole team's positive attitudes towards the students.

Treating students with respect as a colleague and as a professional.

The therapist paced my placement just right from observing to independence.

Communication.

Effective feedback - supportive, ongoing, clear and specific.

Clear explanation and instruction.

Challenge students' thinking and test knowledge

Pushed to work outside comfort zone in order for new learning to occur

Role model

Exemplary knowledge, professional and interpersonal skills

Dedication including taking the time to help, explain, teach or to offer advice. Friendliness, a relaxed manner, patience and a sense of humour.

Role models and leaders in the profession 


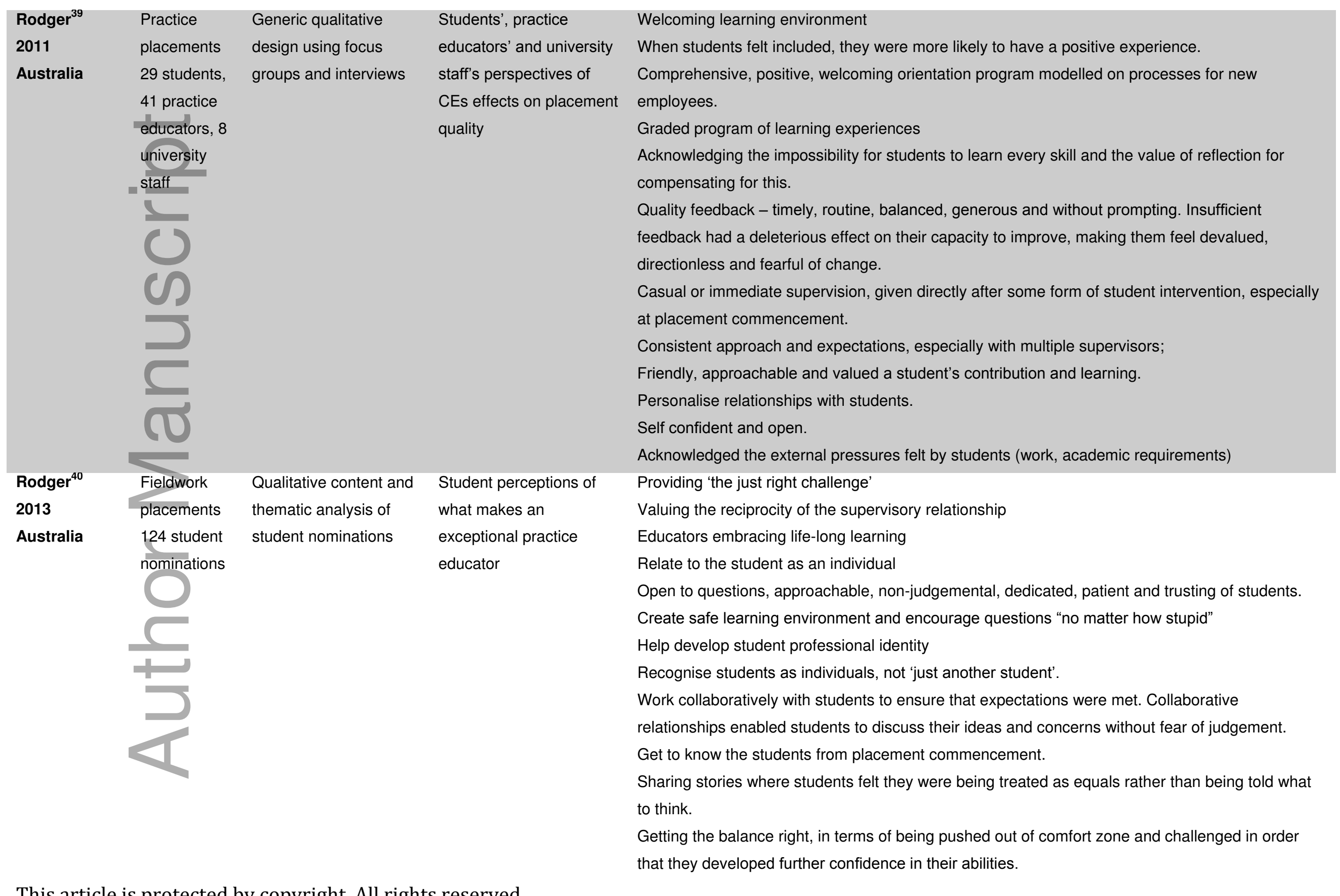

This article is protected by copyright. All rights reserved 
Providing positive, constructive, balanced, encouraging and timely feedback

feedback, that was positive, constructive, balanced, encouraging, timely (often immediate), provided in different ways (written, verbal, scheduled) and helpfully framed as an opportunity for learning.

\begin{tabular}{|c|c|c|c|c|}
\hline & נית & & & $\begin{array}{l}\text { Using examples to show student progression. This enabled them to appreciate changes in their } \\
\text { own performance over time. } \\
\text { Whilst developing autonomy, excellent practice educators also encouraged students to develop } \\
\text { their own therapeutic style, allowing them to integrate the art and the science of practice. }\end{array}$ \\
\hline \multicolumn{5}{|c|}{ Pharmacy } \\
\hline $\begin{array}{l}\text { Astle }^{22} \\
2012 \\
\text { USA }\end{array}$ & $\begin{array}{l}\text { Public and } \\
\text { private } \\
\text { institutions } \\
\text { Students } \\
\text { and } \\
\text { preceptors } \\
\text { from } 119 \\
\text { schools of } \\
\text { pharmacy } \\
\text { across US }\end{array}$ & $\begin{array}{l}\text { Qualitative content } \\
\text { analysis of instruments } \\
\text { used by students to } \\
\text { evaluate preceptors } \\
\text { and student responses } \\
\text { to open-ended survey } \\
\text { regarding qualities of } \\
\text { preceptors }\end{array}$ & $\begin{array}{l}\text { Qualities and } \\
\text { characteristics of } \\
\text { preceptors that assist } \\
\text { student learning found in } \\
\text { student evaluation } \\
\text { instruments. }\end{array}$ & $\begin{array}{l}\text { Professionalism: role model, caring, knowledgeable, competence, professional communication, } \\
\text { enthusiasm for practice } \\
\text { Instructor behaviours: orientation, organised, defines expectations, preceptor defined goals and } \\
\text { objectives, planned activities, learning gap assessment, monitors progress, periodic formal } \\
\text { evaluation, summative evaluation, fair evaluation, formative feedback, conveys concepts, provides } \\
\text { explanations, answers questions, demonstrates, explains reasoning, shares experiences, } \\
\text { preceptor guided goal attainment, dedicates time, preps students, challenges students, making } \\
\text { connections, identification with patients, preceptor guided problem solving, prompts students, open } \\
\text { discussion, encourages questions, relevancy, teachable moments, encourages student self- } \\
\text { assessment, encourages student defined goals and objectives, encourages student } \\
\text { independence, encourages student problem solving, encourages student communication, } \\
\text { encourages student lead, provides positive learning environment, provides optimal physical } \\
\text { environment, provides resources, promotes staff engagement, provides adequate supervision, } \\
\text { provides opportunity to practice, provides opportunity to observe, provides opportunity for } \\
\text { classroom application, provides opportunity for patient contact, provides opportunity for inter- } \\
\text { professional } \\
\text { Supportive role: maintains accessibility, accommodating, willingness to help, motivates students, } \\
\text { concern for student progress, provides positive reinforcement, respect for students, personal } \\
\text { attributes, enthusiasm for teaching, welcomes student feedback } \\
\text { Collaborative: joint negotiation of student activities, views students as part of team, collective } \\
\text { outcomes }\end{array}$ \\
\hline $\begin{array}{l}\lg \lg ^{27} \\
2017\end{array}$ & $\begin{array}{l}\text { Setting not } \\
\text { specified }\end{array}$ & Delphi process & $\begin{array}{l}\text { Views of experienced } \\
\text { preceptors - achieved }\end{array}$ & $\begin{array}{l}\text { Orientation should provide complete information on expectations, grading, and conduct } \\
\text { Feedback }\end{array}$ \\
\hline
\end{tabular}

This article is protected by copyright. All rights reserved 


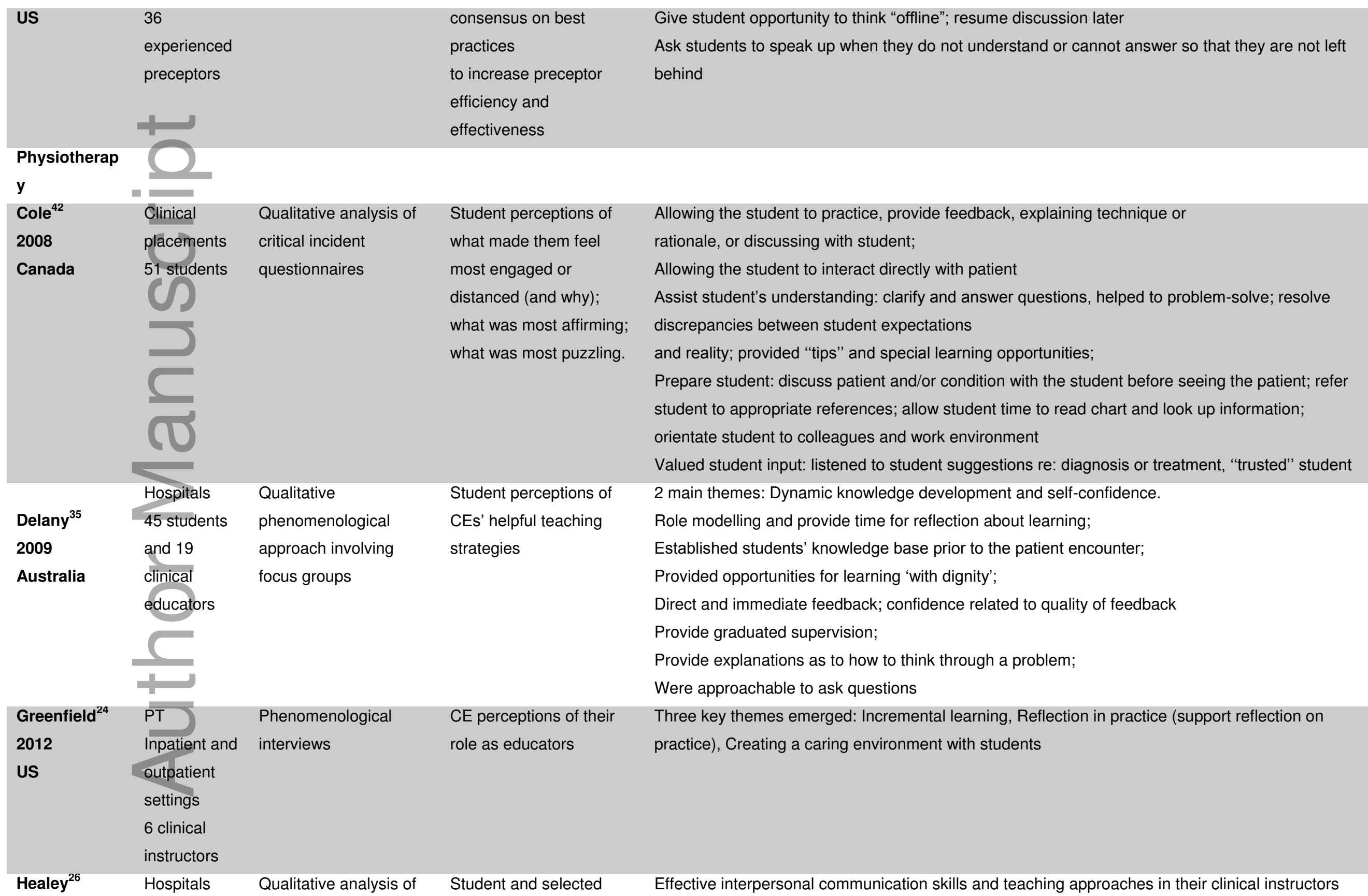

This article is protected by copyright. All rights reserved 
2010,

US

10 students individual interviews

and 9

student-

centred

clinical

instructors

\begin{tabular}{|c|c|c|}
\hline Kelly ${ }^{28}$ & Hospital & Observational study; \\
\hline 2007 & Clinical & case study interviews \\
\hline US & $\begin{array}{l}\text { instructor, } \\
\text { co-worker } \\
\text { and student }\end{array}$ & $\begin{array}{l}\text { with clinical instructor, } \\
\text { former student and } \\
\text { coworker, and audit } \\
\text { trail }\end{array}$ \\
\hline Neville $^{49}$ & Clinical & Content analysis of \\
\hline 1991 & placement & students' responses to \\
\hline UK & 40 students & an open question \\
\hline
\end{tabular}

"student-centred" CE perceptions of CE factors that promote student learning during placement who (a) made them feel comfortable, less anxious, and provided a safe place to learn and take risks, (b) stimulated thinking and understanding by asking questions of them, and (c) provided feedback on their performance that confirmed their strengths and identified areas for improvement. Provide opportunities to interact with patients.

\section{Multi-dimensional input \\ Creating and maintaining an open collegial relationship}

from former student and

their "excellent" CE and

Adapting the experience to the student

Facilitating clinical reasoning

a co-worker summarised Making time for the student

to describe the

Receiving environmental support

instructional reasoning

and teaching strategies

used by an exemplary

clinical instructor

Student perceptions of

Highly frequent, constructive feedback

how CEs contributed to Time with clinical tutors for observation, questioning and the sharing of ideas.

good clinical placement

Encouraging and use a variety of learning materials

Opportunities to see surgery, visit clinics and interact with other professionals

Given responsibility, space, freedom and independence along with guidance and availability of

help if required.

\section{Psychology}

McGinley $^{29}$

2001

US

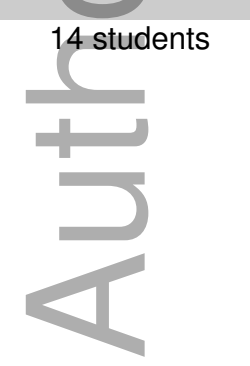

Supportive supervisors who helped their supervisees learn how to utilize their having countertransference in understanding their patients and themselves a supervisor who could explain theory and interventions clearly, supervisors who could give detailed feedback and specific suggestions of how to improve, and supervisors who were flexible in their theoretical orientation and were not rigid about only using process notes as the sole method of supervision. Opportunity to explore their countertransference in a deep and personal manner. Supportive and nonpathologizing supervisor, a flexible supervisor in terms of theoretical orientation and preferred method of supervision (e.g., process notes, audiotape, etc.), and a supervisor well-versed in theory who is able to give detailed feedback. Several subjects mentioned that their best experience involved having a supervisor who respected what they had to say and who treated

This article is protected by copyright. All rights reserved 
them in a collegial manner. In addition, several supervisees stated that they had a better experience in supervision with someone of the same gender. Helpful aspects of supervision included having a supervisor who made the student feel competent and supported, specifically when a supervisor would point out the good rather than just the bad. Subjects also wanted a collaborative flavour to their supervision. They wanted a supervisor who was curious about the supervisee's subjectivity (countertransference), who did not disclose too much and had good boundaries, and would follow the student rather than pushing their own agenda. Finally, subjects also stated that a good match in terms of personality made supervision more pleasurable. The subjects went on to list specific personality traits like a sense of humor and a good interpersonal connection.

$\begin{array}{llll}\text { Rindflesch }^{30} & \text { Clinical } & \text { Phenomenologic study } & \text { Student perceptions of } \\ 2011 & \text { placement at } & \text { using semi structured } & \text { CE behaviours make for } \\ \text { USA } & \text { Mayo clinic } & \text { interviews } & \text { a positive learning } \\ & 9 \text { students } & & \text { experience }\end{array}$

Feedback - constructive, given at an appropriate time, and reciprocal.

Taking time for students included scheduling time with the student throughout the week for questions, to review techniques, or to introduce new material.

Creating a safe environment for a student to ask questions. By encouraging a student to ask about why something is done, the student is becoming more independent in his or her abilities as a future practitioner.

Understanding progression of students for appropriate grading of independence. As students progress through a clinical experience, they typically need more supervision and guidance at the beginning and less at the end.

\section{Social Work}

\begin{tabular}{|c|c|c|c|}
\hline Adams $^{21}$ & Social work & Exploratory qualitative & CE perceptions of the \\
\hline 2011 & Public and & study using focus & characteristics and \\
\hline USA & $\begin{array}{l}\text { private (non- } \\
\text { profit } \\
\text { agencies } \\
19 \text { fieldwork } \\
\text { instructors }\end{array}$ & groups CEs & $\begin{array}{l}\text { attributes for competent } \\
\text { fieldwork instruction }\end{array}$ \\
\hline \multicolumn{4}{|l|}{$\begin{array}{l}\text { Multi- } \\
\text { professional }\end{array}$} \\
\hline $\begin{array}{l}\text { Perram }^{11} \\
2016 \\
\text { Australia }\end{array}$ & $\begin{array}{l}\text { Diagnostic } \\
\text { Radiography } \\
\text {, Nuclear }\end{array}$ & $\begin{array}{l}\text { Thematic analysis of } \\
\text { students answers to } \\
\text { two open questions }\end{array}$ & $\begin{array}{l}\text { Student perceptions of } \\
\text { preferred CE } \\
\text { characteristics }\end{array}$ \\
\hline
\end{tabular}

Role modelling: Demonstrate professional demeanour, attire and work habits, distinguish relationship boundaries between field instructor and student, assist student to distinguish between personal and professional issues in the workplace

Communication: Honest conversations with students about their skill level, set clear and realistic goals with student, provide negative criticism and addressing conflict Nurturing: Demonstrate patience, understanding, and care with student, develop trusting relationship between student and field instructor, provide encouragement and mentoring to student

This article is protected by copyright. All rights reserved

Respectful including being treated like an equal; inspirational including being a role model, enthusiastic about work and student training; supportive; and good teacher including feedback, interactive teaching and provided resources 


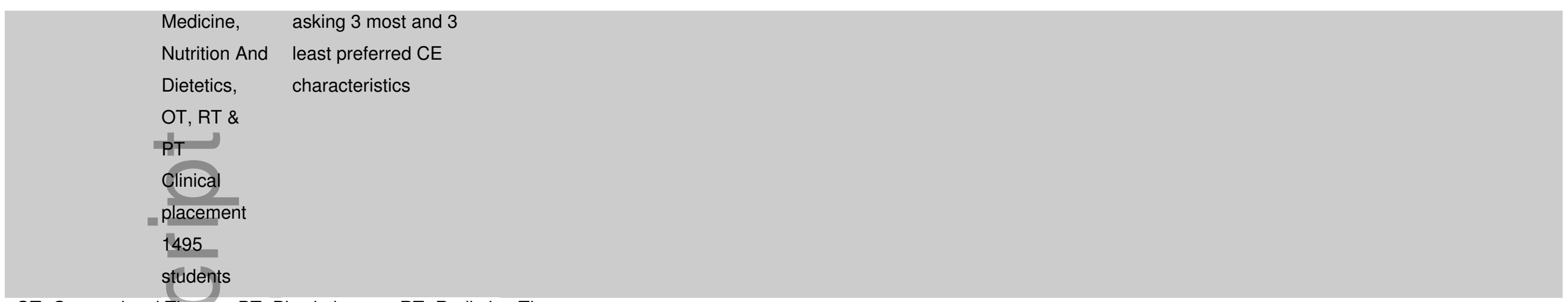

OT=Occupational Therapy PT=Physiotherapy; RT=Radiation Therapy
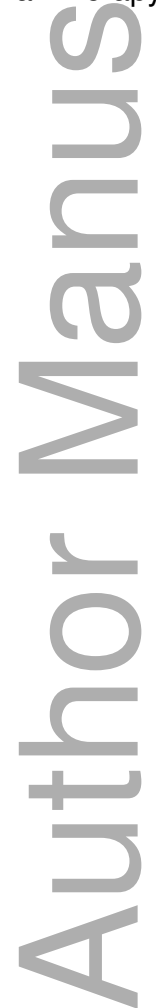

This article is protected by copyright. All rights reserved 
Table 3. Results of thematic analysis of skills and qualities of clinical educators

\begin{tabular}{|c|c|}
\hline Theme & Descriptor \\
\hline \multirow[t]{5}{*}{ Intrinsic and personal attributes of clinical educators } & Friendliness \\
\hline & Kindness \\
\hline & Patience \\
\hline & Relaxed \\
\hline & Welcoming \\
\hline & Honest \\
\hline & Nurturing \\
\hline & Trusting \\
\hline & Willing to help \\
\hline & Interpersonal skills \\
\hline & Approachable \\
\hline & Flexible \\
\hline & Empathic \\
\hline & Self confident \\
\hline & Outgoing \\
\hline & Makes student feel comfortable \\
\hline & Sincere \\
\hline & Enjoys their role \\
\hline & Self aware \\
\hline & Passionate \\
\hline & Sense of humour \\
\hline & RESPECT \\
\hline & $\begin{array}{l}\text { Treat as equal: respect as an individual and } \\
\text { future colleague }\end{array}$ \\
\hline & $\begin{array}{l}\text { - Enhanced confidence and belief in } \\
\text { student's own ability }\end{array}$ \\
\hline & - Sense of professional identity \\
\hline & developed \\
\hline & - Improved motivation \\
\hline \multirow[t]{6}{*}{ Provision of skilful feedback } & Constructive \\
\hline & Prompt \\
\hline & Regular \\
\hline & Not degrading \\
\hline & Balanced \\
\hline & Open to reciprocal feedback \\
\hline
\end{tabular}

This article is protected by copyright. All rights reserved 


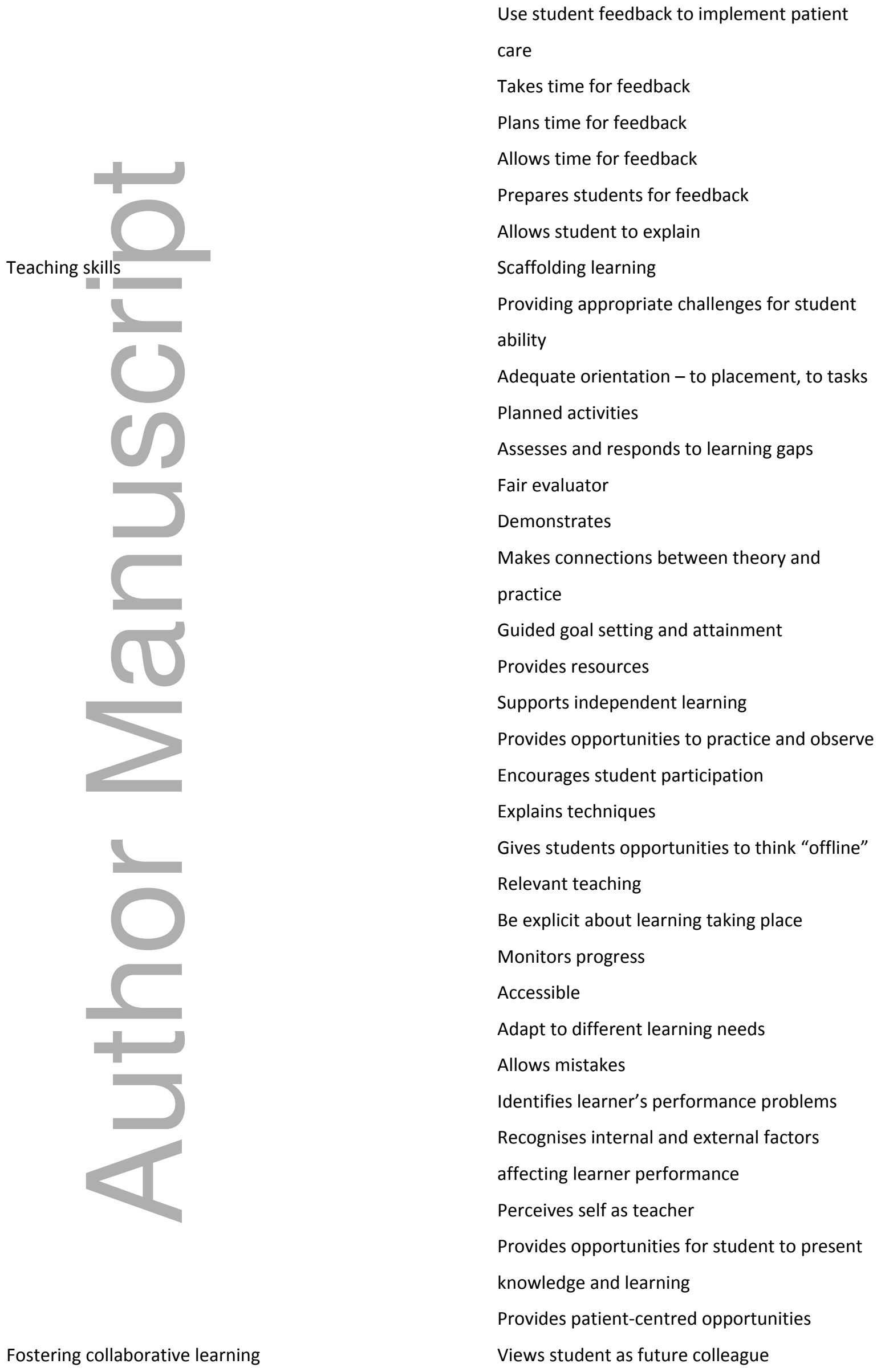

This article is protected by copyright. All rights reserved 


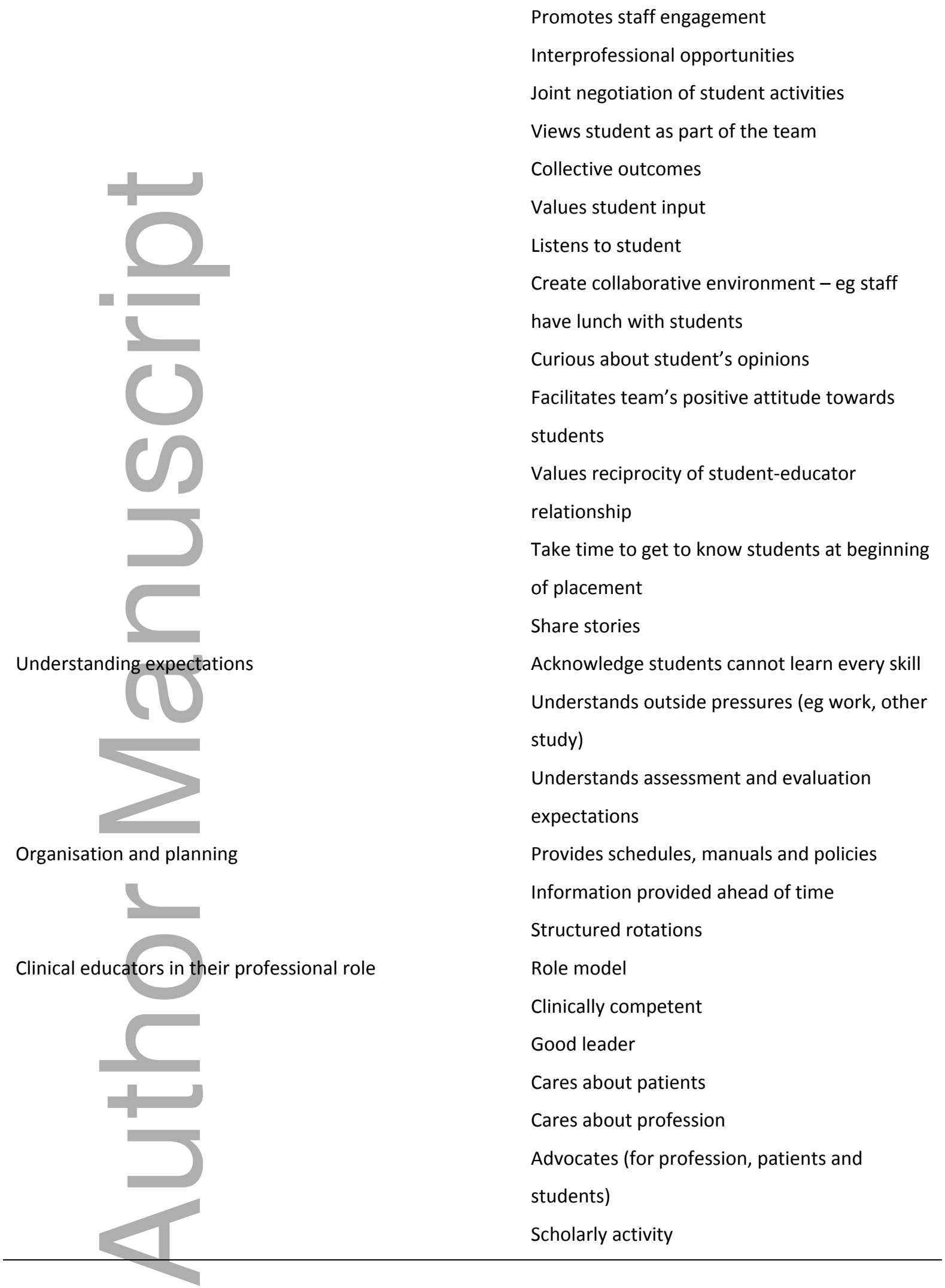




\section{PRISMA 2009 Flow Diagram}
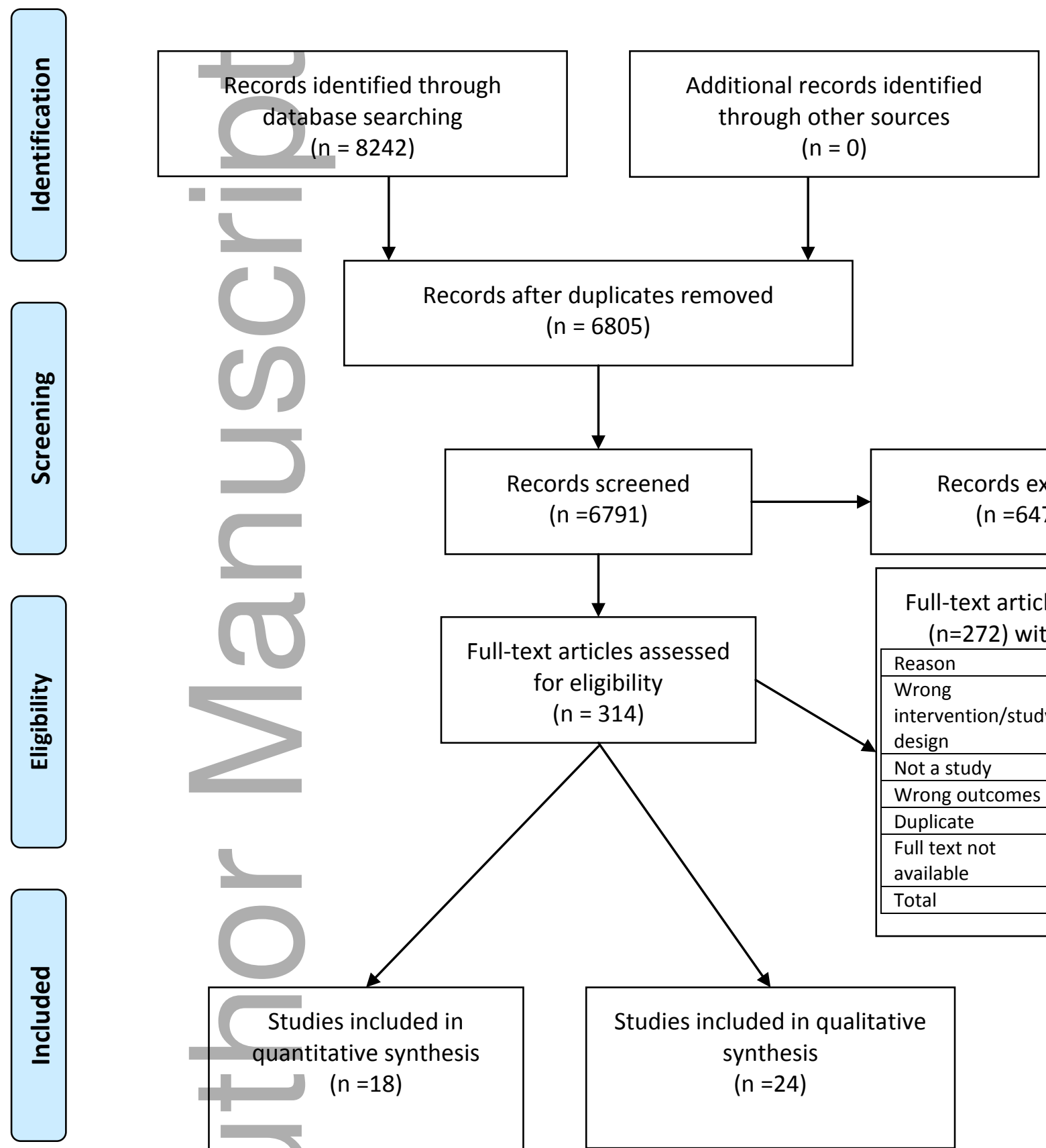

Records screened

( $n=6791)$

Records excluded

( $n=6477$ )

Full-text articles excluded

ull-text articles assessed for eligibility

$(n=314)$ $(n=272)$ with reasons

\begin{tabular}{|c|c|c|}
\hline \multirow{3}{*}{$\begin{array}{l}\text { Full-text articles assessed } \\
\text { for eligibility } \\
\text { ( } n=314)\end{array}$} & \multicolumn{2}{|c|}{$(n=272)$ with reason } \\
\hline & Reason & total \\
\hline & $\begin{array}{l}\text { Wrong } \\
\text { intervention/study }\end{array}$ & 167 \\
\hline & Not a study & 53 \\
\hline & Wrong outcomes & 41 \\
\hline & Duplicate & 6 \\
\hline & $\begin{array}{l}\text { Full text not } \\
\text { available }\end{array}$ & 5 \\
\hline & Total & 272 \\
\hline
\end{tabular}

Studies included in quantitative synthesis $(n=18)$

Studies included in qualitative synthesis $(n=24)$ 


\section{University Library}

\section{- M M N E R VA A gateway to Melbourne's research publications}

Minerva Access is the Institutional Repository of The University of Melbourne

\section{Author/s:}

Gibson, SJ;Porter, J;Anderson, A;Bryce, A;Dart, J;Kellow, N;Meiklejohn, S;Volders, E;Young, A;Palermo, C

Title:

Clinical educators' skills and qualities in allied health: a systematic review

\section{Date:}

2019-05-01

\section{Citation:}

Gibson, S. J., Porter, J., Anderson, A., Bryce, A., Dart, J., Kellow, N., Meiklejohn, S., Volders, E., Young, A. \& Palermo, C. (2019). Clinical educators' skills and qualities in allied health: a systematic review. MEDICAL EDUCATION, 53 (5), pp.432-442. https://doi.org/10.1111/ medu.13782.

Persistent Link:

http://hdl.handle.net/11343/285112 